\title{
Tulane
}

Tulane Economics Working Paper Series

\section{Audits, Audit Effectiveness, and Post-audit Tax Compliance}

\author{
Matthias Kasper \\ Tulane Economics and \\ University of Vienna \\ matthias.kasper@univie.ac.at
}

\author{
James Alm \\ Tulane Economics \\ jalm@tulane.edu
}

Working Paper 2010

September 2020

\begin{abstract}
This study uses a laboratory experiment to investigate the effect of tax audits on post-audit tax compliance. An important feature of our experimental design is the addition of audit "effectiveness" to our audit mechanism, where effectiveness is defined as the share of undeclared income that the tax agency detects in an audit. This addition allows us to examine the effects of audit effectiveness on post-audit compliance. We also study whether tax audits have differential effects on different types of taxpayers, as distinguished by their prior reporting behavior. Contrary to theoretical predictions, we find that tax audits have differential effects on post-audit compliance and that the effectiveness of audits determines these responses; that is, while effective audits increase post-audit tax compliance, ineffective audits have the opposite effect. We also find that tax audits (whether effective or not) increase subsequent compliance of noncompliant taxpayers while they reduce compliance among individuals who have been found to report their income correctly. Finally, we find no evidence that tax audits crowd out the intrinsic motivation to comply of honest individuals. Our findings suggest that the specific deterrent effect of tax audits is more ambiguous than much previous analysis suggests, with these effects dependent on the effectiveness of the audit process and on the taxpayer's prior reporting behavior.
\end{abstract}

Keywords: Tax compliance; Audit effectiveness; Specific deterrence; General deterrence; Laboratory experiments.

JEL codes: C9; H26; H83. 


\title{
Audits, Audit Effectiveness, and Post-audit Tax Compliance ${ }^{1}$
}

\author{
Matthias Kasper ${ }^{*} \$$ \& James Alm*
}

\begin{abstract}
$\underline{\text { Abstract }}$
This study uses a laboratory experiment to investigate the effect of tax audits on post-audit tax compliance. An important feature of our experimental design is the addition of audit "effectiveness" to our audit mechanism, where effectiveness is defined as the share of undeclared income that the tax agency detects in an audit. This addition allows us to examine the effects of audit effectiveness on post-audit compliance. We also study whether tax audits have differential effects on different types of taxpayers, as distinguished by their prior reporting behavior. Contrary to theoretical predictions, we find that tax audits have differential effects on post-audit compliance and that the effectiveness of audits determines these responses; that is, while effective audits increase post-audit tax compliance, ineffective audits have the opposite effect. We also find that tax audits (whether effective or not) increase subsequent compliance of noncompliant taxpayers while they reduce compliance among individuals who have been found to report their income correctly. Finally, we find no evidence that tax audits crowd out the intrinsic motivation to comply of honest individuals. Our findings suggest that the specific deterrent effect of tax audits is more ambiguous than much previous analysis suggests, with these effects dependent on the effectiveness of the audit process and on the taxpayer's prior reporting behavior.
\end{abstract}

Keywords: Tax compliance; Audit effectiveness; Specific deterrence; General deterrence; Laboratory experiments.

JEL Codes: C9; H26; H83.

\footnotetext{
${ }^{1}$ This study was preregistered under: https://osf.io/uhpmw/. It has been approved by the Institutional Review Board of Tulane University (2019-1077) and the Institutional Review Board of the Institute of Work, Economy, and Social Psychology at the University of Vienna (2019/W/001). We thank the Vienna Centre of Experimental Economics (VCEE), University of Vienna, for allowing us to run our experiments in their laboratory. We also thank Steven Sheffrin and the Murphy Institute for the generous support that made this study possible. We appreciate valuable comments from Sebastian Beer, Michele Bernasconi, Juliana Bernhofer, Linda Dezso, Brian Erard, Martin Fochmann, Norman Gemmell, Janet Holzblatt, Erich Kirchler, Christoph Kogler, Leandra Lederman, Mary Marshall, Antoine Malezieux, Luigi Mittone, Stephan Muehlbacher, Jerome Olsen, Matthew Rablen, Steve Sheffrin, Alan Plumley, Ziga Puklavec, and Alexander Siebert, as well as from participants at the Tulane University/Murphy Institute Conference on "Economic and Behavioral Dimensions of Tax Compliance" held in New Orleans, Louisiana in March 2019, at the $9^{\text {th }}$ Annual IRS/TPC Joint Research Conference on Tax Administration held in Washington, D.C. in June 2020, and at the DIBT Seminar at WU Vienna in September 2020.

${ }^{*}$ Tulane University, Department of Economics

${ }^{\$}$ University of Vienna, Department of Applied Psychology

Kasper: matthias.kasper@univie.ac.at; Alm: jalm@tulane.edu
} 


\section{$\underline{\text { 1. Introduction }}$}

Tax audits are an essential instrument in establishing and maintaining compliance, and increasing the number of audits has direct and indirect effects on taxpayer behavior. Audits have direct effects by raising revenue through the assessment of additional taxes, interest, and penalties on individuals who are audited. Additionally, tax audits have indirect effects by deterring future noncompliance among both audited taxpayers (specific deterrence) and unaudited taxpayers (general deterrence). A growing body of research analyzes these direct and indirect deterrent effects of tax audits, and generally shows that more audits lead to more compliance (Alm, 2019; Slemrod, 2019).

However, an important if often neglected feature of tax audits is that they do not always detect tax evasion when it is present and they may even find evasion when it is not in fact present. Early work by Feinstein (1991) suggests that the average detection rates of senior tax examiners are around 50 percent. Indeed, in fiscal year 2018 U.S. taxpayers challenged over $\$ 10$ billion in additional taxes recommended by the Internal Revenue Service (IRS), while almost $\$ 4$ billion of tax and penalties were under appeal in U.S. tax courts (Internal Revenue Service, 2019). This audit "effectiveness", or the tax administration's capacity to detect noncompliance in an audit, seems likely to affect a taxpayer's behavioral responses to enforcement. For example, Gemmell and Ratto (2012) and Beer et al. (2020) suggest that the specific deterrent effect of audits depends on the audit outcome. These studies find that tax audits increase subsequent, or post-audit, compliance among taxpayers who were found to be noncompliant, while they decrease compliance among those who were determined to be compliant. This raises important and unanswered questions about the effect of audit effectiveness on post-audit tax compliance.

Specifically, it remains unclear from existing research whether audit effectiveness especially the lack of effectiveness - affects the specific deterrence effect of enforcement. A related question is whether truly compliant and truly noncompliant taxpayers differ in their behavioral responses to enforcement.

This study addresses these questions by investigating the specific deterrent effect of audits on post-audit tax compliance when audit effectiveness varies. We run a preregistered laboratory experiment with 333 participants in which we test how variation in the risk of detection affects 
subsequent tax compliance. The crucial feature of our experimental design is the addition of audit effectiveness to our audit mechanism, where we define audit effectiveness as the share of undeclared income that the tax agency detects in an audit (Rablen, 2014). This addition allows us to examine the effects of audit effectiveness on post-audit compliance. We also study whether enforcement has differential effects on different types of taxpayers, as distinguished by their prior reporting behavior. Addressing these questions with field data is difficult, even problematic, because tax agencies typically do not know a taxpayer's true tax liability. In particular, the audit outcome is not a perfect measure of a taxpayer's true compliance, given the demonstrated inability of an audit to detect all evasion, so that the identification of audit effectiveness and its effects on truly compliant and noncompliant taxpayers is challenging. In contrast to the use of field data, data generated from a laboratory experiment allows us to introduce changes in audit effectiveness, as well as in audit probability, and thereby allows clean identification of the effects of these changes on post-audit compliance of truly compliant and noncompliant individuals.

Our study differs from the previous literature by making contributions in two important dimensions. First, and most importantly, unlike most existing work, we account for the possibility that tax audits might not detect all undeclared income. This allows us to investigate whether ineffective audits reduce taxpayers' propensity to comply in the future. Second, we investigate whether behavioral responses to enforcement depend on taxpayers' prior reporting behavior. We do this by distinguishing between "compliant", "partly compliant", and "noncompliant" individuals, where compliant taxpayers are defined as those who report all income in the round that is audited, partly compliant taxpayers report some income in this round, and noncompliant taxpayers report zero income in the round. Similarly, we distinguish between "honest", and "dishonest" individuals, where honest taxpayers report all income in all rounds prior to their first audit and dishonest taxpayers report zero income in these rounds. This latter distinction allows us to identify the effect of enforcement on taxpayers who do not respond to changes in the incentives to evade prior to experiencing their first audit. This overall design allows us to disentangle the possible mechanisms by which specific deterrence may drive post-audit tax compliance. We are also able to investigate in detail the effect of audits on different types of taxpayers. Finally, our design allows us to investigate whether presenting the compliance decision as a two-stage compound lottery (where an audit does not result in certain detection) changes a taxpayer's 
willingness to comply compared to a single-stage lottery (where an audit results in certain detection) (Kahneman and Tversky, 1979; Bernasconi and Bernhofer, 2020).

Our results indicate that audit effectiveness is an important determinant of the specific deterrent effect of audits. Taxpayers declare a larger share of their income after experiencing an audit that detects all undeclared income while ineffective audits decrease post-audit compliance. We also find that these responses vary by taxpayer type; that is, prior reporting compliance affects these behavioral responses to audits. While individuals who have been found to underreport their entire income (noncompliant taxpayers) declare substantially more income in subsequent rounds, post-audit compliance declines considerably among those who have been found to report all income correctly (compliant taxpayers). Partly compliant taxpayers, who report some but not all of their income, increase their post-audit compliance after an effective audit but they show the opposite response after an ineffective audit. In addition, we find that audits increase compliance among dishonest individuals who never declared any income before experiencing their first audit. However, we find no evidence that audits "crowd out" compliance among honest taxpayers who reported all income correctly in all rounds prior to their first audit. Finally, while we find no evidence for a misperception of compound detection lotteries.

Our study adds to the literature on behavioral responses to enforcement. Moreover, we provide a new perspective on the tradeoff between audit frequency and audit effectiveness (Rablen, 2014) and the analysis of optimal tax administration (Keen \& Slemrod, 2017). Our results suggest that a complete analysis of a revenue-maximizing audit strategy requires the consideration of postaudit behavior and in particular behavioral responses to audit effectiveness as well as differential responses of compliant and noncompliant taxpayers.

\section{Related Literature}

Prior work on the specific deterrent effect of tax audits typically has used administrative data to analyze the aggregate response of those taxpayers who have been audited. Overall, these 
studies find that enforcement has a positive effect on subsequent reporting compliance. ${ }^{2}$ For example, Kleven et al. (2011) show that tax audits increase self-reported income among Danish taxpayers in the subsequent tax year. Similarly, Advani et al. (2017) find that reported income of self-employed UK taxpayers increases for at least 5 years after an audit, while DeBacker et al. (2018) show that compliance of U.S. taxpayers improves for three years after an audit before ultimately reverting to previous (and lower) levels. A more recent study of U.S. taxpayers by Beer et al. (2020) investigates whether the effect of audits on post-audit reporting behavior depends on the audit outcome, and they find that the specific deterrent effect of tax audits is positive in the aggregate but that subsequent compliance depends on the outcome of the examination. In particular, taxpayers who receive an additional tax assessment as a result of their audit report more income in subsequent years, while those who do not receive an additional assessment report less. This result is in line with a study by Gemmell and Ratto (2012) for the UK that finds that audited taxpayers who were found to be noncompliant report more income in their subsequent tax return than those who were not audited, while taxpayers who were found to be compliant show the opposite response. A study on the effects of audits on VAT compliance in Argentina and Chile by Bergman and Nevarez (2006) also finds that audits have a differential effect on post-audit compliance, however this study finds that audits decrease compliance among those who were found to be cheating.

Overall, these studies suggest that tax audits increase subsequent reporting compliance in the aggregate. However, they raise the question why enforcement appears sometimes to encourage rather than deter future noncompliance. ${ }^{3}$

Several behavioral explanations have been suggested for these results (Kirchler, 2007; Alm, 2019; Beer et al., 2020), but the underlying mechanisms remain unclear. One possible explanation relates to audit effectiveness, or the ability of tax administration to detect evasion during an audit. An ineffective audit might stimulate a taxpayer's willingness to take risks; that is, if an audit fails to detect undeclared income, the taxpayer might infer that the agency is unable to

\footnotetext{
${ }^{2}$ An exception is Erard (1992), who analyzes micro-level data from the U.S. Taxpayer Compliance Measurement Program (TCMP) of the IRS and who finds no significant effect of a prior tax audit on subsequent compliance. ${ }^{3}$ There is some research in criminology that investigates the effect of punishment on an individual's future proclivity for crime. This work suggests mixed evidence for specific deterrence effects, and indeed there is some indication that the experience of punishment might increase, rather than decrease future offending (Cullen et al., 2011, Nagin et al., 2009, Nagin 2013a; Nagin 2013b).
} 
discover cheating and thus underreport his or her income in subsequent years (Andreoni et al., 1998). Indeed, prior work finds that unsanctioned criminal offenses reduce perceived risk of detection and punishment (Matsueda et al., 2006). However, almost all prior work that estimates behavioral responses to tax enforcement assumes that tax audits always detect all undeclared income. The few exceptions employ laboratory experiments to investigate how variation in audit effectiveness affects the general population of taxpayers, rather than those taxpayers who experienced the audit. For example, Alm and McKee (2006) vary the fraction of undeclared income that the tax agency detects in an audit, and, surprisingly, they find higher compliance levels when audit effectiveness is low. Similarly, Bernasconi and Bernhofer (2020) find some support for the hypothesis that ineffective tax audits increase compliance in the aggregate. However, while these two studies suggest that the general deterrent effect of ineffective tax audits might be positive, and potentially even greater than the effect of effective tax audits, the effects of ineffective audits on post-audit tax compliance remain unknown.

A second explanation for the unintended consequences of tax audits is the "bomb crater effect" (Guala and Mittone, 2005; Mittone, 2006). Contrary to the standard model of tax evasion (Allingham and Sandmo, 1972), it is common in laboratory experiments to find that participants declare a smaller share of their income after being audited. Such a response might result from an underestimation of the risk of future audits (Mittone et al., 2017) or from loss-repair motivations (Maciejovsky et al., 2007). However, it remains unclear whether the perceived risk of future examinations is affected by the audit outcome or whether the tendency to make up for past losses pertains to individuals who have been found to be noncompliant. For example, some studies find that a decline in reported income after an audit cannot be explained by loss repair motivations alone because individuals who were found to be compliant also report less income after experiencing an audit (Kastlunger et al., 2009; McKee et al., 2018; Bernasconi and Bernhofer, 2020).

A third potential explanation is that audits have differential effects on different types of taxpayers. Some scholars have suggested that taxpayers comply for different reasons (Erard and Feinstein, 1994; Torgler, 2003; Braithwaite, 2009). While some taxpayers are motivated entirely by the expected value of the evasion gamble, others comply regardless of any incentive to cheat (Braithwaite, 2003). However, such honest taxpayers may find being audited unfair, perceive the 
audit as a breach of trust, or experience negative emotions (Olsen et al., 2018; Enachescu et al., 2019). This experience might crowd out their intrinsic motivation to comply and reduce their propensity to comply in the future (Frey, 1997; Mendoza et al., 2017; Lederman, 2018; Hu and Ben-Ner, 2020). Therefore, a decline in post-audit compliance might also result from honest individuals who are less likely to comply after experiencing an audit.

These prior studies suggest different behavioral explanations of responses to tax audits, but without resolving the actual mechanisms that drive these responses. Our study allows us to discern the potential explanations that have been proposed in the literature. To our knowledge, our study is also the first to investigate the effect of audit effectiveness on post-audit compliance.

\section{Theoretical Foundations}

Theories of deterrence distinguish between threat of punishment and experience of punishment (Chalfin and McCrary, 2007), and the literature in economics focuses mainly on the former. A taxpayer's compliance decision is typically analyzed within an expected utility framework that follows Becker's (1968) economics-of-crime approach, as first formalized by Allingham and Sandmo (1972), Srinivasan (1973), and Yitzhaki (1974) as a decision under risk. The standard model assumes that a taxpayer receives income $I$ and must decide how much to report to the tax agency. Reported income $R$ is taxed at the rate $t$, and unreported income is not taxed. The taxpayer faces the risk of being audited with a probability $p$. In case of an audit, the agency is assumed to detect all undeclared income and to impose a fine $f$ on the undeclared taxes; in case of no audit, the taxpayer simply pays taxes on reported income. All relevant parameters are fixed and known with certainty. The taxpayer chooses $R$ to maximize the expected utility of the evasion gamble, or:

(1) $\quad \mathrm{EU}(\mathrm{I})=(1-p) \mathrm{U}(I-t R)+p \mathrm{U}(I-t R-t f(I-R))$, 
where utility $\mathrm{U}($ ) depends only upon income and $\mathrm{E}$ is the expectation operator. The model predicts that an increase in the audit probability $p$ or the penalty rate $f$ translates into greater compliance. ${ }^{4}$

One major problem with the standard expected utility approach to tax compliance is that the observed levels of tax evasion are not as high as the theory predicts. Taxpayers typically face a low risk of being audited and modest fines for noncompliance. Assuming reasonable risk preferences, a taxpayer that is motivated by financial incentives alone should evade more than the evidence suggests (Skinner and Slemrod, 1985). One explanation for this "tax compliance puzzle" is that taxpayers overestimate the risk of an audit (Alm et al., 1992). An alternative explanation is that a taxpayer's compliance decision is not determined by financial considerations alone. ${ }^{5}$ For example, Erard and Feinstein (1994) point out that some taxpayers are inherently honest and report all income correctly even when they face financial incentives to underreport their income. Still other explanations have been suggested (Alm, 2019).

In particular, several authors have applied rank dependent expected utility theories to tax compliance (Bernasconi, 1998; Yaniv, 1999; Bernasconi and Zanardi, 2005; Alm and McKee, 2006; Dhami and Al-Nowaihi, 2007; Hashimzade, Myles, and Tran-Nam, 2013). These models allow individuals to overweigh the probability of an audit and to exhibit more extreme forms of risk aversion. As a result, they generate predicted levels of compliance that better approximate observed levels. With rank dependent expected utility, the basic maximization problem of equation (1) now becomes

$$
\mathrm{EU}(\mathrm{I})=(1-g)(1-p) \mathrm{U}(I-t R)+g p \mathrm{U}(I-t R-t f(I-R)),
$$

where $g$ serves to overweight the probability of detection and punishment. ${ }^{6}$

All of these models typically assume that an audit detects all undeclared income, but they can be easily adjusted to allow for ineffective audits. In this case both the audit and the outcome

\footnotetext{
${ }^{4}$ There is ample evidence that increasing $p$ and $f$ increases compliance. Alm (2019) and Slemrod (2019) provide comprehensive surveys of the literature.

${ }^{5}$ Kirchler (2007) provides a comprehensive overview of non-financial determinants of tax compliance.

${ }^{6}$ This approach also helps illuminate the roles of information dissemination by the tax authority. Any information provided by the tax authority that describes audits and their ability to detect undeclared income should increase the weighted probability of an audit, while information that suggests the ineffectiveness of audits should lower the weighted probability of an audit. It is straightforward to derive comparative statics results from this approach.
} 
of the audit are uncertain, rendering the evasion gamble a two-stage (compound) decision. For example, in a variation of the expected utility model of equation (1), a taxpayer now faces a compliance choice given by:

$$
\mathrm{EU}(\mathrm{I})=(1-p) \mathrm{U}(I-t R)+p(e \mathrm{U}(I-t R-t f(I-R))+(1-e) \mathrm{U}(I-t R)),
$$

where $e$ is the probability that the audit is effective and detects all undeclared income. The other approaches may be modified along similar lines.

If taxpayers compute compound lotteries correctly, the compliance effect of a change in the audit probability is the same as the effect of an equivalent change in audit effectiveness. ${ }^{7}$ However, presenting a decision as a two-stage compound lottery, rather than a single-stage lottery with identical expected outcomes, might induce a shift in preferences. Assuming a non-linear probability weighing function, where small probabilities are overestimated and large probabilities are underestimated, decision-makers who evaluate the two stages in isolation exhibit different risk preferences than those who consider the compound lottery (Kahneman and Tversky, 1979). Whether a taxpayer misperceives the risk of detection when the audit probability is distinct from the audit effectiveness depends on the magnitude of these parameters, the shape of the taxpayer's probability weighing function, and the taxpayer's cognitive capacity (Dillenberger, 2010; Harrison et al., 2015; Prokosheva, 2016). For example, Bernasconi and Bernhofer (2020) find that taxpayers' probability weighing functions adjust over time due to learning effects.

It is important to note that all of these models predict that audits do not affect a taxpayer's subsequent reporting decision, because they assume that the audit does not provide the taxpayer with new information. As audit and penalty rates are fixed and known, experiencing an audit is merely a case of losing the evasion gamble, and this does not affect post-audit compliance. However, in most cases a taxpayer does not in fact know how likely noncompliance will be detected, and a tax audit might provide new information to the taxpayer that affects post-audit compliance (Snow and Warren, 2007; Kleven et al., 2011). For example, if the audit detects more non-compliance than expected, then the taxpayer may increase his or her prior on the probability of detection and increase post-audit compliance. Conversely, if the audit detects less evasion than

\footnotetext{
${ }^{7}$ Specifically, simplifying equation (3) yields that an $x$ percentage point increase in $p$ is offset by a $1 / x$ percentage point increase in $e$ and vice-versa.
} 
expected, then the taxpayer may decrease his or her prior on the probability of detection and thus decrease post-audit compliance (Slemrod, 2019). The tax audit would have a specific deterrent effect in the former case and a specific counter-deterrent effect in the latter case. However, even after experiencing an audit, a taxpayer does not know exactly the risk of future detection (Alm, 1988; Scotchmer and Slemrod, 1989; Polinsky and Shavell, 2000). This implies that post-audit compliance depends on perceived rather than actual changes in the probability of detection. In fact, prior studies find that the experience of enforcement may change behavior, even absent any change in the underlying probability of detection (Haselhuhn et al., 2012; Earnhart and Friesen, 2013; Simonsohn et al., 2008). This effect is particularly well documented in laboratory experiments on tax compliance, where the relevant tax system parameters are typically unaffected by the audit outcome (Alm, 2019; Alm and Kasper, 2020).

These findings raise unresolved questions about the behavioral determinants of post-audit tax compliance. For example, Mittone (2006) suggests that taxpayers falsely assume dependency of statistically independent events, such as experiencing a random tax audit. Such a bias is related to the "gambler's fallacy", and implies the misconception that a recent audit experience reduces the risk of a future audit ("bomb-crater effect"). Conversely, Spicer and Hero (1985) suggest that audited taxpayers overestimate the risk of future audits because they apply the "availability heuristic" (Kahneman and Tversky, 1973), and assess the probability of a future audit by the ease of recalling their previous audit. In fact, the availability heuristic provides a behavioral rationale for the finding that the audit experience informs a taxpayer's decision to revise upwards or to revise downwards his or her prior on the probability of a future audit even when the relevant parameters do not change. More specifically, Kahneman and Tversky (1974, p. 1128) argue that individuals evaluate the risk of a decision by imagining the negative outcome. If the negative outcome is "vividly portrayed", then this event may "appear exceedingly dangerous, although the ease with which disasters are imagined need not reflect their actual likelihood. Conversely, the risk ... may be grossly underestimated if some possible dangers are either difficult to conceive of, or simply do not come to mind". Audit effectiveness (or the share of undeclared income that the tax agency detected in an audit), along with the audit outcome (or whether or not the taxpayer was found to be noncompliant) of a previous audit should thus affect a taxpayer's assessment of the risk of a future audit. More specifically, the specific deterrent effect of an effective audit should be stronger than the specific deterrent effect of an ineffective audit. Likewise, an audit that found 
the taxpayer to be noncompliant should have a stronger deterrent effect than an audit that found the taxpayer to be compliant.

Another theory assumes that the audit experience changes a taxpayer's motivation to comply, rather than the perceived risk of future detection. Because taxpayers comply for different reasons, the audit experience may have differential effects on post-audit tax compliance, depending on these motivations. For example, an honest taxpayer may find being audited unfair, or perceive the audit as a breach of trust. Similarly, the audit experience might induce negative emotions in honest individuals (Olsen et al., 2018; Enachescu et al., 2019). Tax audits might thus have the potential to crowd out the intrinsic motivation to comply and to reduce post-audit compliance among honest taxpayers (Frey, 1997; Mendoza et al., 2017; Lederman, 2018). Dishonest taxpayers, on the other hand, might respond to an audit by increasing their post-audit compliance because the experience of being punished motivates them to comply more in the future (Kirchler, Hoelzl, and Wahl, 2008; Braithwaite, 2003).

In sum, theoretical studies of tax compliance suggest that financial incentives determine a taxpayer's reporting decision and that increasing the audit probability and the fines for noncompliance deter tax evasion. Even so, behavioral studies suggest that other factors, such as a taxpayer's intrinsic motivation, determine his or her compliance decision. However, the effect of the audit experience on post-audit compliance is not well understood, and the existing literature does not resolve crucial aspects. First, the effect of audit effectiveness on post-audit tax compliance remains unknown. Second, the mechanism by which tax audits affect truly compliant and truly noncompliant taxpayers is also unknown, even though there are various explanations for this behavior; that is, the effects of audits may differ by taxpayer type, especially their previous history of compliance or non-compliance. The next section discusses our experimental design for examining these issues.

\section{Experimental Setup: Design, Procedure, and Sample}

Our experiment implements the fundamental elements of voluntary income tax reporting, following the standard procedure of tax compliance experiments (Alm and Jacobson, 2007). In 
each round of the experiment, participants receive a random amount of income that varies between 2,000 and 3,500 Experimental Currency Units $(\mathrm{ECU})^{8}$. They must decide how much income to report to the tax agency, and they may report any amount between 0 ECU and the amount they received. Reported income is taxed at a rate $t$ of 25 percent $(t=0.25)$. Participants face the risk of being randomly selected for audit. Audit probabilities $p$ range from 0.18 to 0.70 , and tax audits differ in their effectiveness. While audits detect all undeclared income in some rounds, they detect only some fraction of undeclared income in others. Specifically, the audit effectiveness $e$ ranges between 0.30 and 1. Consequently, the overall detection probability (or the product of $p$ and $e$ ) ranges from 0.18 to 0.49 . The fine $f$ for noncompliance is twice the evaded amount that has been detected. Once participants have reported their income, they learn whether they have been audited or not and the outcome of the audit. This process is repeated over 28 rounds in random order. Participants do not know the number of rounds.

Table 1 shows our experimental parameters. We calibrate these parameters such that a "reasonably" risk-averse taxpayer should not report any income to maximize expected profit. ${ }^{9}$ By distinguishing between and introducing variation in the audit probability $p$ and the audit effectiveness $e$, our design enables us to test whether effective versus ineffective audits differ in their capacity to deter future noncompliance of audited taxpayers. Moreover, it also allows us to investigate whether taxpayers misperceive compound lotteries (where $p$ and $e$ are each less than 1) relative to one stage lotteries (where $e=1$ ) with identical detection risk ( $p$ multiplied with $e$ ); see column Audit Type. We also systematically vary the display of information on the audit probability $p$ and the audit effectiveness $e$ to rule out the possibility that order effects drive our results; see column Parameter Order.

All parameters are known to the participants in each round. Also, to facilitate the compliance decision, we program a calculator that shows how declared income translates into after-tax income conditional on audit effectiveness. We provide a screenshot of the experimental task in Appendix A. ${ }^{10}$

\footnotetext{
${ }^{8} 1,000$ ECU equals $€ 3.50$.

9 An individual with "realistic" levels of constant relative risk aversion $(e \leq 1.5)$ would optimally declare zero income for $\mathrm{p}=0.26$ (the average detection probability), $\mathrm{t}=0.25$, and $\mathrm{f}=2$. See Alm (2019) for details.

10 The experiment was programmed in $\mathrm{z}$-Tree (Fischbacher, 2007).
} 
Table 1: Experimental Parameters

\begin{tabular}{|c|c|c|c|c|c|}
\hline Task & Audit Type & $\begin{array}{c}\text { Parameter } \\
\text { Order }\end{array}$ & $\begin{array}{c}\text { Audit } \\
\text { Probability }\end{array}$ & $\begin{array}{c}\text { Audit } \\
\text { Effectiveness }\end{array}$ & $\begin{array}{c}\text { Detection } \\
\text { Risk }\end{array}$ \\
\hline 1 & Effective audit $(e=1)$ & $p$ first & 0.18 & 1.00 & 0.18 \\
\hline 2 & & & 0.21 & 1.00 & 0.21 \\
\hline 3 & & & 0.24 & 1.00 & 0.24 \\
\hline 4 & & & 0.28 & 1.00 & 0.28 \\
\hline 5 & & $e$ first & 0.18 & 1.00 & 0.18 \\
\hline 6 & & & 0.21 & 1.00 & 0.21 \\
\hline 7 & & & 0.24 & 1.00 & 0.24 \\
\hline 8 & & & 0.28 & 1.00 & 0.28 \\
\hline 9 & Low audit probability $(p)$ & $p$ first & 0.30 & 0.60 & 0.18 \\
\hline 10 & & & 0.33 & 0.63 & 0.21 \\
\hline 11 & & & 0.37 & 0.67 & 0.24 \\
\hline 12 & & & 0.40 & 0.70 & 0.28 \\
\hline 13 & & $e$ first & 0.30 & 0.60 & 0.18 \\
\hline 14 & & & 0.33 & 0.63 & 0.21 \\
\hline 15 & & & 0.37 & 0.67 & 0.24 \\
\hline 16 & & & 0.40 & 0.70 & 0.28 \\
\hline 17 & Low audit effectiveness & $p$ first & 0.60 & 0.30 & 0.18 \\
\hline 18 & (e) & & 0.63 & 0.33 & 0.21 \\
\hline 19 & & & 0.67 & 0.37 & 0.24 \\
\hline 20 & & & 0.70 & 0.40 & 0.28 \\
\hline 21 & & $e$ first & 0.60 & 0.30 & 0.18 \\
\hline 22 & & & 0.63 & 0.33 & 0.21 \\
\hline 23 & & & 0.67 & 0.37 & 0.24 \\
\hline 24 & & & 0.70 & 0.40 & 0.28 \\
\hline 25 & High audit probability $(p)$ & $p$ first & 0.60 & 0.60 & 0.36 \\
\hline 26 & and effectiveness $(e)$ & & 0.63 & 0.63 & 0.40 \\
\hline 27 & & & 0.67 & 0.67 & 0.44 \\
\hline 28 & & & 0.70 & 0.70 & 0.49 \\
\hline
\end{tabular}

Notes: Participants face all 28 tasks in random order. Parameters are presented to participants at the beginning of each round. Parameter Order indicates how the audit probability $p$ and the audit effectiveness $e$ are presented to participants ( $p$ before $e$ or vice versa).

The experiment was conducted at the Vienna Center of Experimental Economics (VCEE) in December 2019 and January 2020. Participants were recruited via ORSEE (Greiner, 2015). We 
used a power analysis to determine the sample size, and we pre-registered our study at https://osf.io/uhpmw/. ${ }^{11}$ The final sample $(\mathrm{n}=333)$ comprises data from 13 experimental sessions.

At the beginning of the experiment participants learn that their information is private and that it is impossible to identify individual participants. The study starts with a few demographic questions. Subsequently, participants learn about the compensation mechanism. Each participant receives a show-up fee of $€ 5.00$ and an additional compensation that is based on the after-tax income of a randomly selected round. After reading a detailed introduction to the experimental task and an example of the tax compliance decision, participants must answer two questions on the definition of "audit probability" and "audit effectiveness" correctly before they can proceed. Next, they play three practice rounds. One practice round is not audited, while the two other rounds result in one effective and one ineffective audit, respectively. Participants then proceed to the experiment. After completing the $28^{\text {th }}$ round, they answer a few final questions. The experiment lasts approximately 45 minutes, and the mean payoff is $€ 12.66$.

The participant pool has a slightly larger percentage of female subjects ( 57 percent) than male subjects, and the pool includes students and non-students. The mean age is 26 years (SD = 6.06) with a range from 18 to 59 years. Most participants hold at least a high-school degree (49 percent) and study business (19 percent). While 95 percent indicate that they participated in a laboratory experiment in the past, only 16 percent state that they participated in a study on tax compliance before. Moreover, 29 percent indicate that they self-prepared a tax return in the past.

\section{$\underline{\text { 5. Results }}$}

Table 2 presents descriptive statistics. We observe 9324 compliance decisions from 333 individuals. The actual audit probability was 0.44 , and the average audit effectiveness was 0.66. Our main dependent variable is the Compliance rate, defined as the share of received income that

\footnotetext{
${ }^{11}$ Our target sample size estimate is based on a power analysis that indicated that a sample size of $\mathrm{N}=327$ is required to detect a difference between two means (mean compliance rate after an effective versus an ineffective audit) with the following parameters: power $=0.95$, alpha $=0.05$, Cohen's $d=0.2$, t-test for two dependent means (two-tailed).
} 
was reported to the tax agency. The mean compliance rate across all subjects and all rounds was $0.54(\mathrm{SD}=0.41)$, which indicates substantial underreporting in the aggregate.

Table 2: Data Description

\begin{tabular}{|c|c|c|c|}
\hline Variable & Description & Mean & SD \\
\hline \multicolumn{4}{|l|}{ Dependent Variables } \\
\hline Compliance rate & Reported income divided by received income & 0.54 & 0.41 \\
\hline Evaded income & Income not reported on tax return (in ECU) & 1248.97 & 1156.05 \\
\hline \multicolumn{4}{|c|}{ Experimental Treatment Variables } \\
\hline Received income & Income received (in ECU) & 2700.16 & 430.04 \\
\hline Detection risk & Audit probability multiplied with audit effectiveness & 0.26 & 0.08 \\
\hline Audit probability & Probability of being audited & 0.44 & 0.19 \\
\hline Audit effectiveness & Share of evaded income that the audit detects & 0.66 & 0.25 \\
\hline Audit probability first & $=1$ if audit probability presented before audit effectiveness & 0.57 & 0.50 \\
\hline Round after audit & $=1$ if round succeeds an audit and 0 if round is audited & & \\
\hline Experienced effectiveness & Effectiveness when audited & 0.63 & 0.24 \\
\hline Noncompliant & $=1$ if reported income equals 0 & 0.25 & 0.44 \\
\hline Compliant & $=1$ if reported income equals received income & 0.26 & 0.44 \\
\hline Dishonest & $=1$ if reported income equals 0 for each round prior to first audit & 0.11 & 0.31 \\
\hline Honest & $\begin{array}{l}=1 \text { if reported income equals received income for each round } \\
\text { prior to first audit }\end{array}$ & 0.14 & 0.35 \\
\hline \multicolumn{4}{|l|}{ Demographic Variables } \\
\hline Female & $=1$ if participant is female & 0.57 & 0.50 \\
\hline Age & Participant's age in years & 25.94 & 6.06 \\
\hline Higher education & $=1$ if completed Bachelor Studies or higher & 0.51 & 0.49 \\
\hline Economics major & $=1$ if Major in Economics & 0.08 & 0.27 \\
\hline German speaking & $=1$ if Austrian or German & 0.48 & 0.50 \\
\hline Prior experiments & $=1$ if prior participation in laboratory experiments & 0.95 & 0.23 \\
\hline Prior tax experiments & $=1$ if prior participation in tax experiments & 0.16 & 0.37 \\
\hline Self-preparation & $=1$ if self-prepared tax return in the past & 0.29 & 0.46 \\
\hline Risk seeking ${ }^{\#}$ & Do you like to gamble? ( 0 to 9$)$ & 4.36 & 2.36 \\
\hline Income maximization ${ }^{\#}$ & To what extent did you try to maximize your income? ( 0 to 9 ) & 6.27 & 2.34 \\
\hline Tax morale ${ }^{\#}$ & $\begin{array}{l}\text { Do you think cheating on tax if you have a chance can be } \\
\text { justified? ( } 0 \text { to } 9)\end{array}$ & 6.05 & 2.68 \\
\hline
\end{tabular}

Notes: ${ }^{\#}$ denotes a scale from 0 to 9 , where higher values indicate more risk-seeking, more income maximization, and higher tax morale.

Figure 1 shows a bimodal distribution of the Compliance rate. Participants report zero income in 0.25 of all rounds and all income in 0.26 of all rounds. This indicates that participants 
differ fundamentally in their propensity to comply. While some appear to be motivated entirely by the expected value of the evasion gamble and never report any income, others report their income correctly irrespective of any incentive to cheat. Moreover, we find that female participants are substantially more compliant (mean compliance $=0.60$ ) than male participants (mean compliance $=0.43)$.

Figure 1: Histogram of the Compliance Rate for Male and Female Participants

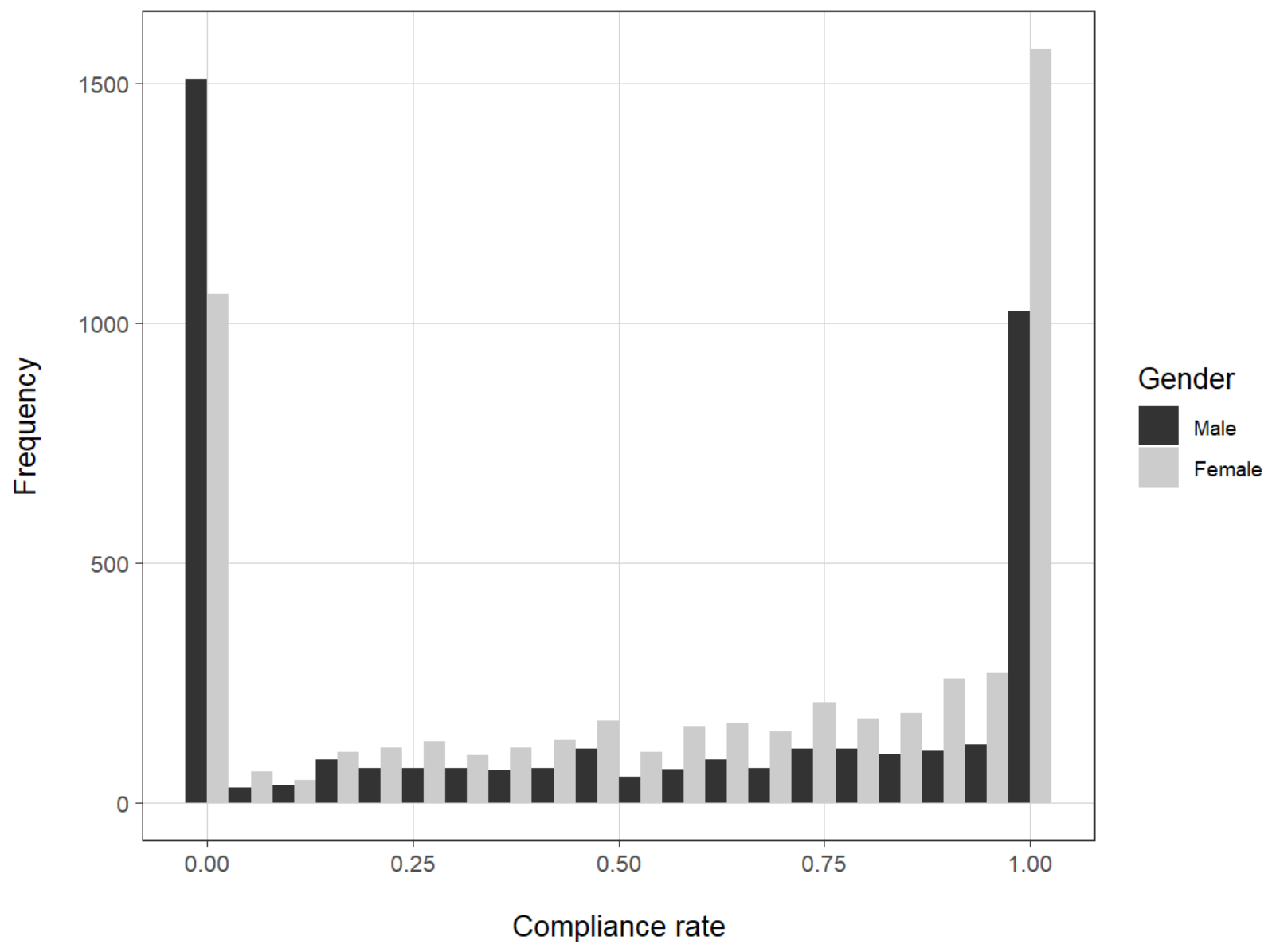

To investigate the effect of tax audits on post-audit compliance, we compare mean compliance levels in the rounds that were audited to compliance levels in subsequent rounds. Figure 2 depicts the compliance implications of effective and ineffective tax audits. We refer to the round that was audited as Round 0 , where this round represents data from all rounds that were 
audited (4131 rounds). Round 1 then comprises data from all rounds that immediately follow a tax audit (4016 rounds), and Rounds 2 to 5 summarize information from subsequent rounds. ${ }^{12}$

Panel 1 indicates that the aggregate effect of tax audits on subsequent compliance tends to be slightly negative. However, behavioral responses depend strongly on audit effectiveness. Participants who experience an effective audit declare a larger share of their income in subsequent rounds, while post-audit compliance declines among taxpayers who experience an ineffective audit. Panel 1 also suggests that behavioral responses to ineffective audits seem to be slightly more persistent than behavioral responses to effective audits.

Panels 2 to 4 depict the effect of audits on taxpayers who were noncompliant, partly compliant, or fully compliant in the round that was audited. Overall, the effect of audits on postaudit compliance depends strongly on prior reporting levels. While audits increase post-audit compliance considerably among noncompliant taxpayers (or those who did not report any income in the round that was audited) (Panel 2), the behavioral response of partly compliant individuals (who reported some but not all of their income) depends strongly on audit effectiveness (Panel 3); those taxpayers increase their post-audit compliance after an effective audit and decrease their post-audit compliance after an ineffective audit. Finally, audits decrease post-audit compliance substantially among fully compliant individuals who reported all income in the round that was audited (Panel 4).

\footnotetext{
${ }^{12}$ In case of a subsequent audit (e.g. in Round 3), information from that round is reflected both in Round 3 (reported income three rounds after experiencing an audit) and in Round 0 (reported income in a round that is audited). The reporting decision in the subsequent round is then reflected in Round 1 so that Graph 2 depicts the average effect of audits on post-audit compliance.
} 
Figure 2: Effect of Audits on Post-audit Compliance

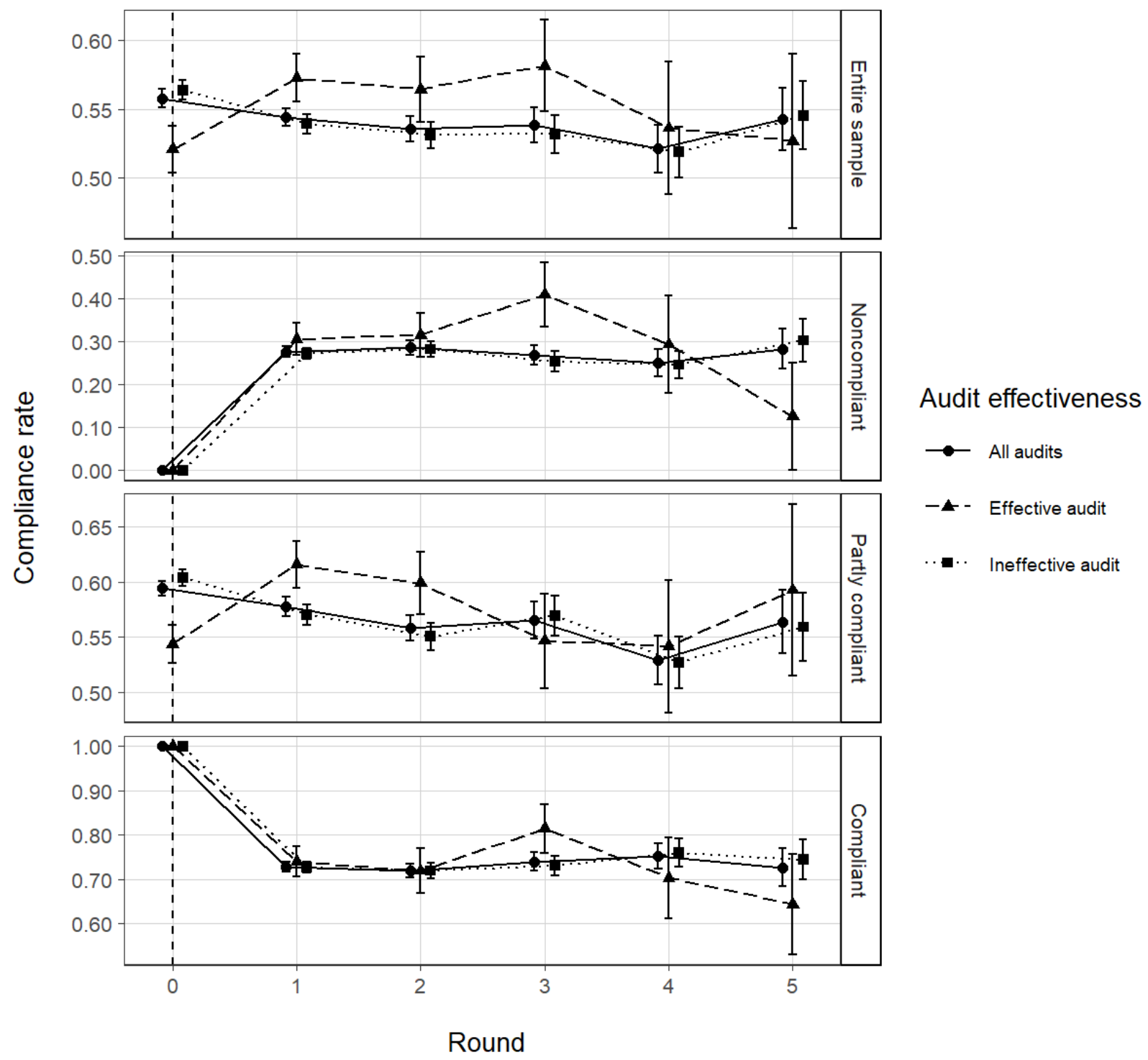

Notes: Taxpayers were audited after declaring their income in Round 0 (dashed vertical line) and not audited again through Round 5. Panel 1 (Entire Sample) comprises data from all individuals (4131 observations in Round 0). Taxpayers who were found to be Noncompliant (Panel 2) did not report any income in Round 0 (1049 observations in Round 0). Taxpayers who were found to be Partly Compliant (Panel 3) reported some but not all of their income in Round 0 (1916 observations in Round 0). Taxpayers who were found to be Compliant (Panel 4) reported all income to the tax agency in Round 0 (1166 observations in Round 0 ). Effective audits detect all undeclared income. Ineffective audits detect between 30 percent and 70 percent of undeclared income. Error bars represent standard errors.

Our descriptive analyses indicate that individuals differ fundamentally in their propensity to comply and that the audit effectiveness has a strong effect on post-audit tax compliance. While effective audits increase post-audit compliance, ineffective audits have the opposite effect. 
Moreover, audits have differential effects on compliant and noncompliant (including partly compliant) taxpayers. While taxpayers who reported all their income to the tax agency in the round that was audited declare less in subsequent rounds, post-audit compliance increases among individuals who were found to be noncompliant. In contrast, the effect of audits on the post-audit compliance of partly compliant taxpayers depends on the audit effectiveness. The next subsection employs regression analyses to analyze the effect of audit effectiveness on post-audit tax compliance of compliant and noncompliant taxpayers.

\subsection{Regression Results}

We report our main results in Tables 3 and 4. Table 3 presents regression results on the effect of audits on tax reporting in the round that immediately follows the audit, while Table 4 shows behavioral responses in subsequent rounds (two to five rounds after the audit). ${ }^{13}$ Our regression results provide strong evidence that tax audits have differential effects on post-audit compliance, effects that vary by audit effectiveness and also by taxpayer type.

Table 3 reveals three important results. First, we find that audits have the potential to increase or to decrease post-audit tax compliance. Second, we find that effective audits have a more positive effect on post-audit tax compliance than ineffective audits. Third, we find that audits have differential effects on compliant and noncompliant (including partly compliant) taxpayers. More specifically, audits increase the post-audit compliance of noncompliant individuals, who did not report any income in the round that was audited, while they reduce the post-audit compliance of compliant taxpayers, who have been found to report all income correctly. Finally, Table 4 reveals that audits have sustainable effects on post-audit compliance. While the audit effectiveness has a positive effect on the post-audit compliance of taxpayers who did not report some fraction

\footnotetext{
${ }^{13}$ To identify the effect of audits on post-audit compliance, we compare compliance rates in rounds that were audited (Round $0, \mathrm{n}_{0}=4131$ ) to compliance rates in the five subsequent rounds ( $\mathrm{n}_{1}=4016, \mathrm{n}_{2}=2113, \mathrm{n}_{3}=1112, \mathrm{n}_{4}=$ $592, \mathrm{n}_{5}=312$ ). Taxpayers were only audited once (in Round 0 ) through Round 5. Our main analysis thus identifies within-subject variation in reporting compliance that results from experiencing an audit. To test the robustness of our results, we also compare reporting compliance across all audited and unaudited rounds. These results are presented in Appendix Tables B2 and B3. Our results are unaffected.
} 
of their income for three rounds after the audit, the differential responses of compliant and noncompliant individuals persists for five rounds after the audit.

Our baseline specifications (Models 1 and 2) estimate the effect of basic economic factors (Received income), deterrence factors (Detection risk, Audit probability, Audit effectiveness), the audit experience (Round after audit), and several Demographic Variables (listed in Table 2) on the Compliance rate. ${ }^{14}$ The interaction Round after audit $x$ Experienced effectiveness measures the effect of the experienced audit effectiveness on post-audit compliance. While the Detection Risk (the product of the audit probability and the audit effectiveness) has a strong effect on compliance, the insignificant coefficients on Audit probability and Audit effectiveness provide no indication for a systematic misperception of either of these factors. This suggests that the risk of detection drives compliance decisions. In contrast, the presentation of the compliance decision as a one-stage or a two-stage compound lottery with identical expected outcomes does not drive compliance decisions. Similarly, the insignificant coefficient on Audit probability first shows that whether the audit probability is shown before the audit effectiveness (or vice versa) has no effect on compliance. Importantly, Models 1 and 2 indicate that post-audit compliance depends strongly on audit effectiveness. While the coefficient of Round after audit indicates that ineffective audits reduce the post-audit compliance rate by 3 percentage points in the aggregate, the interaction term Round after audit $x$ Experienced effectiveness is significant and positive. All else equal, we estimate that experiencing an effective audit increases post-audit compliance by 3 percentage points.

Models 3 to 6 complement these findings and show that prior compliance has a strong effect on post-audit compliance. Specifically, Models 3 and 4 add the indicator variable Noncompliant that equals 1 if a taxpayer did not report any income in a round that was audited. The negative coefficient on Round after audit shows that audits reduce post-audit compliance among taxpayers who reported at least some fraction of their income by approximately 8 percentage points, while the insignificant interaction term Round after audit $x$ Experienced effectiveness suggests that the experienced audit effectiveness has no effect on the post-audit compliance of these taxpayers. As discussed below, these results are driven by compliant

\footnotetext{
${ }^{14}$ To test the robustness of our results, we also use Evaded income as the dependent variable. These results are presented in Appendix Tables B4. Our results are unaffected.
} 
taxpayers, whose substantial decline in post-audit compliance is unaffected by the audit effectiveness. Moreover, Models 3 and 4 show that audits increase post-audit tax compliance of Noncompliant taxpayers substantially. On average, Noncompliant individuals report over fifty percentage points less income than other taxpayers. However, noncompliant individuals increase their reported income by approximately 20 percentage points one round after experiencing an audit (Round after audit $x$ Noncompliant).

Finally, Models 5 and 6 replace the indicator variable Noncompliant with the indicator variable Compliant that equals 1 if a taxpayer reported all income in a round that was audited. Our estimates indicate that ineffective audits increase the post-audit compliance of individuals who did not report at least some fraction of their income by approximately 5 percentage points (Round after audit) and that an effective audit increases post-audit compliance of those taxpayers by 6 percentage points compared to an ineffective audit (Round after audit $x$ Experienced Effectiveness). Moreover, we estimate that Compliant taxpayers, who report over 40 percentage points more income than other taxpayers, reduce their post-audit tax compliance by approximately 24 percentage points in the round after an audit (Round after audit $x$ Compliant).

With regard to the demographic variables, we find that age and being female have a positive effect on compliance, that participants from German-speaking countries are less compliant than participants from other countries, and that individuals who indicated in the post-experimental survey that they tried to maximize their income reported smaller shares of their income. 
Table 3: Effect of Audits One Round After the Audit

\begin{tabular}{|c|c|c|c|c|c|c|}
\hline \multicolumn{7}{|c|}{ Dependent variable: Compliance rate } \\
\hline Independent variable & (1) & (2) & (3) & (4) & (5) & (6) \\
\hline Intercept & $\begin{array}{c}0.2984^{* * *} \\
(0.0433)\end{array}$ & $\begin{array}{c}0.3718^{* * *} \\
(0.0945)\end{array}$ & $\begin{array}{c}0.4659^{* * *} \\
(0.0379)\end{array}$ & $\begin{array}{c}0.4897^{* * *} \\
(0.0679)\end{array}$ & $\begin{array}{c}0.2256^{* * *} \\
(0.0412)\end{array}$ & $\begin{array}{c}0.2821^{* * *} \\
(0.0804)\end{array}$ \\
\hline Received income & $\begin{array}{c}-0.0145^{* * *} \\
(0.0030)\end{array}$ & $\begin{array}{c}-0.0146^{* * *} \\
(0.0030)\end{array}$ & $\begin{array}{c}-0.0140^{* * *} \\
(0.0028)\end{array}$ & $\begin{array}{c}-0.0142^{* * *} \\
(0.0028)\end{array}$ & $\begin{array}{c}-0.0109^{* * *} \\
(0.0030)\end{array}$ & $\begin{array}{c}-0.0111^{* * *} \\
(0.0030)\end{array}$ \\
\hline Detection risk & $\begin{array}{c}0.0082^{* * *} \\
(0.0009)\end{array}$ & $\begin{array}{c}0.0082^{* * *} \\
(0.0009)\end{array}$ & $\begin{array}{c}0.0056^{* * *} \\
(0.0008)\end{array}$ & $\begin{array}{c}0.0056^{* * *} \\
(0.0008)\end{array}$ & $\begin{array}{c}0.0071^{* * *} \\
(0.0009)\end{array}$ & $\begin{array}{c}0.0071^{* * *} \\
(0.0009)\end{array}$ \\
\hline Audit probability & $\begin{array}{c}0.0003 \\
(0.0006)\end{array}$ & $\begin{array}{c}0.0003 \\
(0.0006)\end{array}$ & $\begin{array}{l}0.0012^{* *} \\
(0.0006)\end{array}$ & $\begin{array}{l}0.0012^{* *} \\
(0.0006)\end{array}$ & $\begin{array}{c}0.0001 \\
(0.0006)\end{array}$ & $\begin{array}{c}0.0001 \\
(0.0006)\end{array}$ \\
\hline Audit effectiveness & $\begin{array}{c}0.0002 \\
(0.0004)\end{array}$ & $\begin{array}{c}0.0002 \\
(0.0004)\end{array}$ & $\begin{array}{c}0.0004 \\
(0.0004)\end{array}$ & $\begin{array}{c}0.0004 \\
(0.0004)\end{array}$ & $\begin{array}{c}0.0001 \\
(0.0004)\end{array}$ & $\begin{array}{c}0.0001 \\
(0.0004)\end{array}$ \\
\hline Audit probability first & $\begin{array}{l}-0.0035 \\
(0.0064)\end{array}$ & $\begin{array}{l}-0.0034 \\
(0.0064)\end{array}$ & $\begin{array}{l}-0.0036 \\
(0.0059)\end{array}$ & $\begin{array}{l}-0.0035 \\
(0.0059)\end{array}$ & $\begin{array}{l}-0.0032 \\
(0.0063)\end{array}$ & $\begin{array}{l}-0.0031 \\
(0.0063)\end{array}$ \\
\hline Round after audit & $\begin{array}{c}-0.0274^{* *} \\
(0.0123)\end{array}$ & $\begin{array}{c}-0.0273^{* *} \\
(0.0123)\end{array}$ & $\begin{array}{c}-0.0829^{* * *} \\
(0.0120)\end{array}$ & $\begin{array}{c}-0.0835^{* * *} \\
(0.0121)\end{array}$ & $\begin{array}{c}0.0463^{* * *} \\
(0.0127)\end{array}$ & $\begin{array}{c}0.0465^{* * *} \\
(0.0127)\end{array}$ \\
\hline $\begin{array}{l}\text { Round after audit } \mathrm{x} \\
\text { Experienced } \\
\text { effectiveness }\end{array}$ & $\begin{array}{c}0.0006^{* * *} \\
(0.0002)\end{array}$ & $\begin{array}{c}0.0006^{* * *} \\
(0.0002)\end{array}$ & $\begin{array}{c}0.0002 \\
(0.0002)\end{array}$ & $\begin{array}{c}0.0002 \\
(0.0002)\end{array}$ & $\begin{array}{c}0.0006^{* * *} \\
(0.0002)\end{array}$ & $\begin{array}{c}0.0006^{* * *} \\
(0.0002)\end{array}$ \\
\hline Noncompliant & & & $\begin{array}{c}-0.5369^{* * *} \\
(0.0105)\end{array}$ & $\begin{array}{c}-0.5340^{* * *} \\
(0.0106)\end{array}$ & & \\
\hline $\begin{array}{l}\text { Round after audit x } \\
\text { Noncompliant }\end{array}$ & & & $\begin{array}{l}0.2829^{* * *} \\
(0.0124)\end{array}$ & $\begin{array}{c}0.2836^{* * *} \\
(0.0124)\end{array}$ & & \\
\hline Compliant & & & & & $\begin{array}{c}0.4285^{* * *} \\
(0.0108)\end{array}$ & $\begin{array}{c}0.4272^{* * *} \\
(0.0108)\end{array}$ \\
\hline $\begin{array}{l}\text { Round after audit } \mathrm{x} \\
\text { Compliant }\end{array}$ & & & & & $\begin{array}{c}-0.2861^{* * *} \\
(0.0128)\end{array}$ & $\begin{array}{c}-0.2864^{* * *} \\
(0.0128)\end{array}$ \\
\hline Demographic variables & & included & & included & & included \\
\hline Observations & 8147 & 8147 & 8147 & 8147 & 8147 & 8147 \\
\hline $\mathrm{N}$ & 333 & 333 & 333 & 333 & 333 & 333 \\
\hline $\mathrm{R}^{2}$ & 0.681 & 0.656 & 0.633 & 0.644 & 0.638 & 0.637 \\
\hline
\end{tabular}

Notes: $* * *$, and $* * *$ indicate significance at the $10 \%, 5 \%$, and $1 \%$ level. Robust standard errors (in parentheses) are clustered at the individual level. Continuous predictors are scaled. 
Table 4 presents regression results for subsequent rounds (two to five rounds after the audit). The effect of Received income on compliance remains negative across all specifications, while the effect of Detection risk on compliance remains large and positive. Again, the coefficients of Audit probability and Audit effectiveness provide no indication for a systematic misperception of either of these factors.

The interaction terms Round after audit $x$ Experienced effectiveness suggest that the effect of Audit effectiveness is strongest for taxpayers who did not report some fraction of their income. Among those taxpayers, effective audits increase post-audit compliance by 6 percentage points two rounds after the audit (Model 9), and 8 percentage points three rounds after the audit (Model 12), compared to ineffective audits. Surprisingly, our estimates indicate that this effect reverts over time: while the interaction effect is insignificant four rounds after the audit (Model 15), experienced audit effectiveness has a negative effect on audited taxpayers who were not found to be compliant five rounds after the audit (Model 18), where an effective audit reduces post-audit compliance by 17 percentage points compared to an ineffective audit.

The differential responses of Noncompliant and Compliant taxpayers are even more persistent. We estimate that audits increase post-audit compliance of Noncompliant taxpayers for five rounds after the audit (Round after audit $x$ Noncompliant). While the increase in post-audit compliance attenuates from approximately 20 percentage points two rounds after the audit (Model 8) to approximately 14 percentage points increase four rounds after the audit (Model 14), we estimate that post-audit compliance levels of taxpayers who have been found to be noncompliant are 20 percentage points higher five rounds after the audit than they were before the audit (Model 17). Similarly, our estimates indicate that the audit experience reduces post-audit compliance of Compliant taxpayers for five rounds (Round after audit $x$ Compliant). Those taxpayers report approximately 24 percentage points less income two rounds after an audit (Model 9), and five rounds after the audit (Model 18) post-audit compliance is still approximately 10 percentage points below pre-audit levels. 
Table 4: Effect of Audits on Post-audit Tax Compliance

\begin{tabular}{|c|c|c|c|c|c|c|c|c|c|c|c|c|}
\hline \multirow[b]{2}{*}{$\begin{array}{l}\text { Independent } \\
\text { variable }\end{array}$} & \multicolumn{3}{|c|}{ Two rounds after the audit } & \multicolumn{3}{|c|}{ Three rounds after the audit } & \multicolumn{3}{|c|}{ Four rounds after the audit } & \multicolumn{3}{|c|}{ Five rounds after the audit } \\
\hline & $(7)$ & $(8)$ & (9) & $(10)$ & $(11)$ & $(12)$ & $(13)$ & $(14)$ & $(15)$ & $(16)$ & $(17)$ & $(18)$ \\
\hline Intercept & $\begin{array}{c}0.5014^{* * *} \\
(0.0987)\end{array}$ & $\begin{array}{c}0.6003^{* * *} \\
(0.0644)\end{array}$ & $\begin{array}{c}0.4069^{* * *} \\
(0.0790)\end{array}$ & $\begin{array}{c}0.4382^{* * *} \\
(0.1013)\end{array}$ & $\begin{array}{c}0.6118^{* * *} \\
(0.0593)\end{array}$ & $\begin{array}{c}0.3720^{* * *} \\
(0.0785)\end{array}$ & $\begin{array}{c}0.4483^{* * *} \\
(0.1052)\end{array}$ & $\begin{array}{c}0.6109^{* * *} \\
(0.0559)\end{array}$ & $\begin{array}{c}0.3405^{* * *} \\
(0.0783)\end{array}$ & $\begin{array}{c}0.4328^{* * *} \\
(0.1049)\end{array}$ & $\begin{array}{c}0.6401^{* * *} \\
(0.0542)\end{array}$ & $\begin{array}{c}0.3489^{* * *} \\
(0.0777)\end{array}$ \\
\hline Received income & $\begin{array}{c}-0.0166^{* * *} \\
(0.0033)\end{array}$ & $\begin{array}{c}-0.0149^{* * *} \\
(0.0029)\end{array}$ & $\begin{array}{c}-0.0134^{* * *} \\
(0.0033)\end{array}$ & $\begin{array}{c}-0.0148^{* * *} \\
(0.0037)\end{array}$ & $\begin{array}{c}-0.0128^{* * *} \\
(0.0028)\end{array}$ & $\begin{array}{c}-0.0076^{* *} \\
(0.0034)\end{array}$ & $\begin{array}{c}-0.0143^{* * *} \\
(0.0038)\end{array}$ & $\begin{array}{c}-0.0114^{* * *} \\
(0.0026)\end{array}$ & $\begin{array}{c}-0.0059^{*} \\
(0.0034)\end{array}$ & $\begin{array}{c}-0.0131^{* * *} \\
(0.0040)\end{array}$ & $\begin{array}{c}-0.0103^{* * *} \\
(0.0026)\end{array}$ & $\begin{array}{l}-0.0044 \\
(0.0034)\end{array}$ \\
\hline Detection risk & $\begin{array}{c}0.0084^{* * *} \\
(0.0010)\end{array}$ & $\begin{array}{c}0.0041^{* * *} \\
(0.0008)\end{array}$ & $\begin{array}{c}0.0069^{* * *} \\
(0.0010)\end{array}$ & $\begin{array}{c}0.0085^{* * *} \\
(0.0011)\end{array}$ & $\begin{array}{c}0.0032^{* * *} \\
(0.0008)\end{array}$ & $\begin{array}{c}0.0064^{* * *} \\
(0.0010)\end{array}$ & $\begin{array}{c}0.0084^{* * *} \\
(0.0011)\end{array}$ & $\begin{array}{c}0.0026^{* * *} \\
(0.0008)\end{array}$ & $\begin{array}{c}0.0058^{* * *} \\
(0.0010)\end{array}$ & $\begin{array}{c}0.0087^{* * *} \\
(0.0012)\end{array}$ & $\begin{array}{c}0.0028^{* * *} \\
(0.0008)\end{array}$ & $\begin{array}{c}0.0062^{* * *} \\
(0.0011)\end{array}$ \\
\hline Audit probability & $\begin{array}{l}-0.0008 \\
(0.0007)\end{array}$ & $\begin{array}{c}0.0008 \\
(0.0006)\end{array}$ & $\begin{array}{l}-0.0013^{*} \\
(0.0007)\end{array}$ & $\begin{array}{l}-0.0003 \\
(0.0008)\end{array}$ & $\begin{array}{l}0.0013^{* *} \\
(0.0006)\end{array}$ & $\begin{array}{l}-0.0008 \\
(0.0008)\end{array}$ & $\begin{array}{l}-0.0001 \\
(0.0008)\end{array}$ & $\begin{array}{l}0.0015^{* *} \\
(0.0006)\end{array}$ & $\begin{array}{l}-0.0006 \\
(0.0008)\end{array}$ & $\begin{array}{l}-0.0001 \\
(0.0009)\end{array}$ & $\begin{array}{l}0.0013^{* *} \\
(0.0006)\end{array}$ & $\begin{array}{l}-0.0009 \\
(0.0008)\end{array}$ \\
\hline Audit effectiveness & $\begin{array}{l}-0.0005 \\
(0.0005)\end{array}$ & $\begin{array}{c}0.0001 \\
(0.0004)\end{array}$ & $\begin{array}{l}-0.0006 \\
(0.0005)\end{array}$ & $\begin{array}{l}-0.0002 \\
(0.0006)\end{array}$ & $\begin{array}{c}0.0003 \\
(0.0004)\end{array}$ & $\begin{array}{l}-0.0004 \\
(0.0005)\end{array}$ & $\begin{array}{c}-0.0002 \\
(0.0006)\end{array}$ & $\begin{array}{c}0.0004 \\
(0.0004)\end{array}$ & $\begin{array}{l}-0.0001 \\
(0.0005)\end{array}$ & $\begin{array}{c}-0.0003 \\
(0.0006)\end{array}$ & $\begin{array}{c}0.0001 \\
(0.0004)\end{array}$ & $\begin{array}{l}-0.0004 \\
(0.0006)\end{array}$ \\
\hline $\begin{array}{l}\text { Audit probability } \\
\text { first }\end{array}$ & $\begin{array}{l}-0.0034 \\
(0.0072)\end{array}$ & $\begin{array}{l}-0.0002 \\
(0.0061)\end{array}$ & $\begin{array}{l}-0.0002 \\
(0.0070)\end{array}$ & $\begin{array}{l}-0.0033 \\
(0.0080)\end{array}$ & $\begin{array}{l}-0.0063 \\
(0.0060)\end{array}$ & $\begin{array}{l}-0.0054 \\
(0.0074)\end{array}$ & $\begin{array}{l}-0.0070 \\
(0.0081)\end{array}$ & $\begin{array}{l}-0.0056 \\
(0.0057)\end{array}$ & $\begin{array}{l}-0.0084 \\
(0.0073)\end{array}$ & $\begin{array}{l}-0.0091 \\
(0.0086)\end{array}$ & $\begin{array}{l}-0.0060 \\
(0.0056)\end{array}$ & $\begin{array}{l}-0.0080 \\
(0.0074)\end{array}$ \\
\hline Round after audit & $\begin{array}{l}-0.0262 \\
(0.0165)\end{array}$ & $\begin{array}{c}-0.0889^{* * *} \\
(0.0148)\end{array}$ & $\begin{array}{l}0.0374^{* *} \\
(0.0166)\end{array}$ & $\begin{array}{l}-0.0394^{*} \\
(0.0225)\end{array}$ & $\begin{array}{c}-0.0833^{* * *} \\
(0.0176)\end{array}$ & $\begin{array}{c}0.0158 \\
(0.0213)\end{array}$ & $\begin{array}{l}-0.0450 \\
(0.0294)\end{array}$ & $\begin{array}{c}-0.0660^{* * *} \\
(0.0217)\end{array}$ & $\begin{array}{c}0.0060 \\
(0.0269)\end{array}$ & $\begin{array}{c}0.0631 \\
(0.0408)\end{array}$ & $\begin{array}{c}0.0298 \\
(0.0281)\end{array}$ & $\begin{array}{c}0.1537^{* * *} \\
(0.0359)\end{array}$ \\
\hline $\begin{array}{l}\text { Round after audit } \mathrm{x} \\
\text { Experienced } \\
\text { effectiveness }\end{array}$ & $\begin{array}{c}0.0004 \\
(0.0003)\end{array}$ & $\begin{array}{c}0.0002 \\
(0.0002)\end{array}$ & $\begin{array}{l}0.0006^{* *} \\
(0.0003)\end{array}$ & $\begin{array}{c}0.0006 \\
(0.0004)\end{array}$ & $\begin{array}{c}0.0003 \\
(0.0003)\end{array}$ & $\begin{array}{l}0.0008^{* *} \\
(0.0003)\end{array}$ & $\begin{array}{c}0.0004 \\
(0.0005)\end{array}$ & $\begin{array}{l}-0.0002 \\
(0.0003)\end{array}$ & $\begin{array}{c}0.0003 \\
(0.0004)\end{array}$ & $\begin{array}{c}-0.0015^{* *} \\
(0.0007)\end{array}$ & $\begin{array}{c}-0.0017^{* * *} \\
(0.0004)\end{array}$ & $\begin{array}{c}-0.0017^{* * *} \\
(0.0006)\end{array}$ \\
\hline Noncompliant & & $\begin{array}{c}-0.6178^{* * *} \\
(0.0100)\end{array}$ & & & $\begin{array}{c}-0.6781^{* * *} \\
(0.0091)\end{array}$ & & & $\begin{array}{c}-0.7079^{* * *} \\
(0.0084)\end{array}$ & & & $\begin{array}{c}-0.7268^{* * *} \\
(0.0081)\end{array}$ & \\
\hline $\begin{array}{l}\text { Round after audit } \mathrm{x} \\
\text { Noncompliant }\end{array}$ & & $\begin{array}{c}0.2839^{* * *} \\
(0.0137)\end{array}$ & & & $\begin{array}{c}0.2326^{* * *} \\
(0.0152)\end{array}$ & & & $\begin{array}{c}0.2091^{* * *} \\
(0.0182)\end{array}$ & & & $\begin{array}{l}0.2281^{* * *} \\
(0.0241)\end{array}$ & \\
\hline Compliant & & & $\begin{array}{c}0.4736^{* * *} \\
(0.0109)\end{array}$ & & & $\begin{array}{c}0.5220^{* * *} \\
(0.0108)\end{array}$ & & & $\begin{array}{c}0.5534^{* * *} \\
(0.0104)\end{array}$ & & & $\begin{array}{c}0.5693^{* * *} \\
(0.0103)\end{array}$ \\
\hline $\begin{array}{l}\text { Round after audit } \mathrm{x} \\
\text { Compliant }\end{array}$ & & & $\begin{array}{c}-0.2768^{* * *} \\
(0.0150)\end{array}$ & & & $\begin{array}{c}-0.2471^{* * *} \\
(0.0182)\end{array}$ & & & $\begin{array}{c}-0.1959^{* * *} \\
(0.0225)\end{array}$ & & & $\begin{array}{c}-0.2596^{* * *} \\
(0.0301)\end{array}$ \\
\hline $\begin{array}{l}\text { Demographic } \\
\text { variables }\end{array}$ & included & included & included & included & included & included & included & Included & included & included & included & included \\
\hline Observations & 6244 & 6244 & 6244 & 5255 & 5255 & 5255 & 4723 & 4723 & 4723 & 4443 & 4443 & 4,443 \\
\hline $\mathrm{n}$ & 333 & 333 & 333 & 333 & 333 & 333 & 333 & 333 & 333 & 333 & 333 & 333 \\
\hline $\mathrm{R}^{2}$ & 0.668 & 0.704 & 0.654 & 0.662 & 0.770 & 0.687 & 0.694 & 0.813 & 0.731 & 0.678 & 0.832 & 0.738 \\
\hline
\end{tabular}

Notes: $*, * *$, and $* * *$ indicate significance at the $10 \%, 5 \%$, and $1 \%$ level. Robust standard errors (in parentheses) are clustered at the individual level. Continuous predictors are scaled. 
To further investigate the effect of tax audits on individuals who differ in their propensity to comply, Table 5 reports estimates for the effect of the first audit that taxpayers experience on the Compliance rate in the subsequent round. This reduces the number of observations to 666 ( $n=333$ ), and, due to the small sample size, we do not distinguish between different levels of audit effectiveness. As noted earlier, our experimental parameters are calibrated such that the profitmaximizing strategy is to report zero income in every round. To identify the effect of an audit on individuals who are motivated entirely by the expected value of the evasion gamble, we introduce the indicator variable Dishonest $\left(n_{D}=37\right.$ ), which equals 1 if a taxpayer reported zero income in all rounds prior to his or her first audit. The interaction Round after audit $x$ Dishonest thus identifies the effect of the first audit on Dishonest taxpayers.

Our estimates indicate that the experience of the first audit increases the post-audit Compliance rate of Dishonest taxpayers by 19 percentage points (Models 19 and 20). Conversely, Models 21 and 22 investigate the hypothesis that audits "crowd out" the intrinsic motivation to comply of honest taxpayers, who comply regardless of any incentive to cheat. We replace the variable Dishonest with the indicator variable Honest, which equals 1 if a taxpayer reported all income in all rounds prior to his or her first audit $\left(n_{H}=46\right)$. The interaction Round after audit $x$ Honest thus identifies the effect of the first audit on Honest taxpayers. Our estimates indicate that the first audit does not reduce the post-audit compliance of Honest taxpayers ( $p=.105$ in Model 21 and $\mathrm{p}=.115$ in Model 22). Therefore, we find no support for the hypothesis that audits crowd out the intrinsic motivation to comply among honest individuals. 
Table 5: Effect of First Audits on Dishonest and Honest Taxpayers

\begin{tabular}{|c|c|c|c|c|}
\hline \multicolumn{5}{|c|}{ Dependent variable: Compliance rate } \\
\hline Independent variable & (19) & (20) & (21) & (22) \\
\hline Intercept & $\begin{array}{l}0.3996^{* *} \\
(0.1730)\end{array}$ & $\begin{array}{l}0.3839^{*} \\
(0.1959)\end{array}$ & $\begin{array}{c}0.2803 \\
(0.1812)\end{array}$ & $\begin{array}{c}0.2688 \\
(0.2030)\end{array}$ \\
\hline Received income & $\begin{array}{l}0.0001 \\
(0.0127)\end{array}$ & $\begin{array}{c}0.0014 \\
(0.0130)\end{array}$ & $\begin{array}{c}0.0002 \\
(0.0133)\end{array}$ & $\begin{array}{c}0.0016 \\
(0.0133)\end{array}$ \\
\hline Detection risk & $\begin{array}{c}0.0100^{* * *} \\
(0.0038)\end{array}$ & $\begin{array}{c}0.0110^{* * *} \\
(0.0039)\end{array}$ & $\begin{array}{c}0.0116^{* * *} \\
(0.0040)\end{array}$ & $\begin{array}{c}0.0121^{* * *} \\
(0.0040)\end{array}$ \\
\hline Audit probability & $\begin{array}{l}-0.0004 \\
(0.0028)\end{array}$ & $\begin{array}{l}-0.0008 \\
(0.0029)\end{array}$ & $\begin{array}{l}-0.0013 \\
(0.0030)\end{array}$ & $\begin{array}{l}-0.0014 \\
(0.0030)\end{array}$ \\
\hline Audit effectiveness & $\begin{array}{c}0.0002 \\
(0.0020)\end{array}$ & $\begin{array}{l}-0.0002 \\
(0.0020)\end{array}$ & $\begin{array}{l}-0.0005 \\
(0.0020)\end{array}$ & $\begin{array}{l}-0.0007 \\
(0.0020)\end{array}$ \\
\hline Audit probability first & $\begin{array}{l}-0.0024 \\
(0.0278)\end{array}$ & $\begin{array}{l}-0.0021 \\
(0.0284)\end{array}$ & $\begin{array}{c}0.0152 \\
(0.0291)\end{array}$ & $\begin{array}{c}0.0118 \\
(0.0291)\end{array}$ \\
\hline Round after audit & $\begin{array}{l}-0.0088 \\
(0.0223)\end{array}$ & $\begin{array}{l}-0.0082 \\
(0.0232)\end{array}$ & $\begin{array}{c}0.0325 \\
(0.0230)\end{array}$ & $\begin{array}{c}0.0326 \\
(0.0232)\end{array}$ \\
\hline Dishonest & $\begin{array}{c}-0.6459^{* * *} \\
(0.0648)\end{array}$ & $\begin{array}{c}-0.5676^{* * *} \\
(0.0657)\end{array}$ & & \\
\hline Round after audit $\mathrm{x}$ Dishonest & $\begin{array}{c}0.1893^{* * *} \\
(0.0658)\end{array}$ & $\begin{array}{c}0.1903^{* * *} \\
(0.0685)\end{array}$ & & \\
\hline Honest & & & $\begin{array}{c}0.4725^{* * *} \\
(0.0637)\end{array}$ & $\begin{array}{c}0.3972^{* * *} \\
(0.0656)\end{array}$ \\
\hline Round after audit $\mathrm{x}$ Honest & & & $\begin{array}{l}-0.1008 \\
(0.0622)\end{array}$ & $\begin{array}{l}-0.0988 \\
(0.0628)\end{array}$ \\
\hline Demographic variables & & included & & included \\
\hline Observations & 666 & 666 & 666 & 666 \\
\hline $\mathrm{N}$ & 333 & 333 & 333 & 333 \\
\hline $\mathrm{R}^{2}$ & 0.605 & 0.577 & 0.612 & 0.604 \\
\hline
\end{tabular}

Notes: $*, * *$, and $* * *$ indicate significance at the $10 \%, 5 \%$, and $1 \%$ level. Robust standard errors (in parentheses) are clustered at the individual level. Continuous predictors are scaled. 


\subsection{Supplemental Robustness Analysis}

We have estimated several additional regression models to examine the robustness of our findings, as reported in Appendix B. First, we investigate whether the experienced fine for noncompliance, rather than the audit effectiveness, determines post-audit compliance by adding Experienced fine to our explanatory variables (Models I to V in Table B1), where Experienced fine is defined as the actual fine paid by the individual when audited. The interaction Round after audit $x$ Experienced fine captures changes in post-audit compliance that result from the experienced fine, while the term Round after audit $x$ Experienced effectiveness $x$ Experienced fine identifies whether behavioral responses to differences in audit effectiveness depend on the experienced fine. Our estimates indicate that audit effectiveness, but not the experienced fine, determines post-audit tax compliance. However, while the interaction Round after audit $x$ Experienced fine is insignificant, the significant 3-way interaction indicates that effective audits increase post-audit tax compliance when experienced fines are high, but not when experienced fines are low. The dynamic between the experienced audit effectiveness and the experienced fine is depicted in Figure B1.

Second, we change the structure of our analysis such that we identify differences between all audited and all unaudited rounds (Tables B2 and B3). These analyses employ indicator variables that equal 1 if a taxpayer was audited in the last round (Audit last round), if the taxpayer was noncompliant (Noncompliant) or compliant (Compliant) in the last round, and if the taxpayer was dishonest (Dishonest) or honest (Honest) prior to experiencing the first audit. This results in larger sample sizes, because every experimental round, rather than just audited rounds and the five succeeding rounds are analyzed. All results are in line with our main results.

Finally, we test whether our results are robust to changes in the dependent variable (Table B4), with Models XVI to XX testing whether using Evaded income (i.e., received income minus reported income) as the dependent variable affects the results. As expected, changing the dependent variable does not affect our results. Likewise, the effect of the first audit on the evaded income of Dishonest and Honest individuals is in line with the results reported above, although Model XX indicates a marginally significant increase in evaded income among Honest taxpayers who were audited in the last round $(\mathrm{p}=0.082)$. 


\section{Conclusions}

How do tax audits affect post-audit tax compliance? In this paper we study the specific deterrent effect of tax audits by analyzing two aspects of behavioral responses to enforcement. First, we investigate how ineffective audits that do not detect all undeclared income affect subsequent reporting behavior. Second, we analyze how tax audits affect truly compliant and truly noncompliant taxpayers, by examining the behavioral mechanisms that drive these responses. Moreover, our research design also allows us to test whether presenting the compliance decision as a two-stage compound lottery with uncertain detection affects compliance decisions relative to a single-stage lottery with certain detection. We investigate these issues in a preregistered laboratory experiment in which taxpayers receive income and decide how much they declare to the tax agency. They face the risk of being audited and a fine for undeclared income that is detected on audit. We introduce variation in the audit probability and audit effectiveness in order to assess behavioral responses to changes in these factors.

Our results suggest that tax audits have different effects on post-audit compliance and that behavioral responses to enforcement are not always in line with the assumptions of the standard model of tax evasion (Allingham and Sandmo, 1972). Specifically, our first main result relates to the role of audit effectiveness on the impact of audits. We find that tax audits do not have a positive effect on subsequent reporting compliance in the aggregate. Instead, we find that the specific deterrent effect of tax audits depends strongly on audit effectiveness. While taxpayers who experienced an effective audit that detected all undeclared income comply more in subsequent periods, those who experienced an ineffective audit show the opposite response. This suggests that ineffective tax audits stimulate risk-taking and that taxpayers whose underreporting was not detected during an audit contribute to the decline in post-audit compliance found in some prior studies (Gemmell and Ratto, 2012; Beer et al., 2020). As compound compliance lotteries (with ineffective audits) do not affect compliance compared to single-stage lotteries (with certain detection), we can rule out that a misperception of either of these factors drives behavioral responses to effective and ineffective audits. Indeed, it is important to recognize that there was no uncertainly present in our design: participants knew the exact consequences of their reporting decisions, which reduces the margin for such bias. We also find that compliance choices are 
unaffected by the way in which the relevant factors are presented (e.g., showing the audit probability before the audit effectiveness and vice versa).

Our second main result relates to the ways in which audits affect specific deterrence of different types of taxpayers. We find consistent and robust evidence that post-audit compliance depends on taxpayers' prior reporting behavior. While taxpayers who were caught evading their entire income report substantially more income for five rounds after the audit, individuals who reported all income in the round that was audited reduce their post-audit tax payments for five rounds. This result provides a more nuanced perspective on the finding that audited taxpayers generally tend to underestimate the risk of future examinations (Guala and Mittone, 2005; Mittone, 2006; Mittone et al., 2017), and indicates that loss-repair motivations alone do not explain behavioral responses to enforcement because taxpayers who were found to be compliant seem to infer that the risk of a future examination is low (Maciejovsky et al., 2007; McKee et al., 2018).

An alternative explanation for differential responses to audits is that audits affect different types of taxpayers differently. In particular, some studies suggest that compliant taxpayers might reduce their post-audit compliance because these individuals perceive the audit as a sign of distrust of the tax agency, which reduces their intrinsic motivation to comply in the future (Frey, 1997; Mendoza et al., 2017; Lederman, 2018; Hu and Ben-Ner, 2020). To investigate this hypothesis, we analyze how audits affect honest and dishonest taxpayers who always report all or zero income prior to their first audit. While post-audit compliance increases among dishonest individuals, the effect of audits on the reporting compliance of honest taxpayers is insignificant. Thus, we do not find evidence that experiencing an audit crowds out the intrinsic motivation to comply of honest taxpayers.

Taken together, our findings challenge the standard result - and common assumption - that more audits always lead to more compliance. This has important implications for tax administrations. Our study suggests that increasing the capacity of tax audits to detect noncompliance and improving the targeting of noncompliant taxpayers are both crucial in establishing and maintaining compliance.

Future work should investigate the effect of the audit selection mechanism on subsequent compliance. While in practice most audits target taxpayers with a relatively high likelihood of 
noncompliance, our study employs a random audit selection mechanism, common to many if not all laboratory experiments. A taxpayer, and particularly a compliant taxpayer, who has been randomly selected for audit might fall for the "bomb crater" fallacy, underestimate the risk of a future examination, and thus decide to report less income after the audit. Conversely, taxpayers who have been targeted based on their prior reporting behavior might be less likely to exhibit such bias. Finally, future studies might investigate how uncertainty about the audit probability and the audit effectiveness affects subsequent compliance.

\section{$\underline{\text { References }}$}

Advani, A., Elming, W., \& Shaw, J. (2017). “The dynamic effects of tax audits.”, No. W17/24. London, UK: The Institute for Fiscal Studies.

Allingham, M. G., \& Sandmo, A. (1972). "Income tax evasion: A theoretical analysis." Journal of Public Economics 1 (3-4): 323-338.

Alm, J. (2019). "What motivates tax compliance?” Journal of Economic Surveys 33 (2): 353388.

Alm, J., \& Jacobson, S. (2007). "Using laboratory experiments in public economics.” National Tax Journal 60 (1): 129-152.

Alm, J., \& Kasper, M. (2020). "Laboratory Experiments", in B. Van Rooij \& D. Sokol, ed., Cambridge Handbook of Compliance. Cambridge, UK: Cambridge University Pres (in press).

Alm, J., McClelland, G. H., \& Schulze, W. D. (1992). “Why do people pay taxes?” Journal of Public Economics 48: 21-38.

Alm, J., \& McKee, M. (2006). "Audit certainty, audit productivity, and taxpayer compliance.” National Tax Journal 59 (4): 801-816.

Andreoni, J., Erard, B., \& Feinstein, J. S. (1998). “Tax compliance.” The Journal of Economic Literature 36 (2): 818-860.

Becker, G. S. (1968). "Crime and punishment - An economic approach.” The Journal of Political Economy 76 (2): 169-217. 
Beer, S., Kasper, M., Kirchler, E., \& Erard, B. (2020). "Do audits deter or provoke future tax noncompliance? Evidence on self-employed taxpayers." CESifo Economic Studies 66 (3): 248-264.

Bergman, M., \& Nevarez, A. (2006). "Do audits enhance compliance? An empirical assessment of VAT enforcement." National Tax Journal 59 (4): 817-832.

Bernasconi, M. (1998). "Tax evasion and orders of risk aversion." Journal of Public Economics 67 (1): 123-134.

Bernasconi, M., \& Bernhofer, J. (2020). "Catch me if you can: Testing the reduction of compound lotteries axiom in a tax compliance experiment." Journal of Behavioral and Experimental Economics 84, Article 101479.

Bernasconi, M., and Zanardi, A. (2004). "Tax evasion, tax rates, and reference dependence." FinanzArchiv 60 (3): 422-445.

Braithwaite, V. (2003). “Taxing democracy: understanding tax avoidance and tax evasion”, in V. Braithwaite, ed., Dancing with Tax Authorities: Motivational Postures and Noncompliant Actions. Aldershot, UK: Ashgate,15-39.

Braithwaite, V. (2009) Defiance in Taxation and Governance - Resisting and Dismissing Authority in a Democracy. Cheltenham, UK and Northhampton, MA: Edward Elgar Publishing Limited.

Chalfin, A., \& McCrary, J. (2017). “Criminal deterrence: A review of the literature.” The Journal of Economic Literature 55 (1), 5-48.

Cullen, F. T., Jonson, C. L., \& Nagin, D. S. (2011). "Prisons do not reduce recidivism: The high cost of ignoring science." The Prison Journal 91(3_suppl), 48S-65S.

DeBacker, J., Heim, B. T., Tran, A., \& Yuskavage, A. (2018). “Once bitten, twice shy? The lasting impact of IRS audits on individual tax reporting." The Journal of Law and Economics 61 (1): 1-35.

Dhami, S., and al-Nowaihi, A. (2007). "Why do people pay taxes? Prospect theory versus expected utility theory." Journal of Economic Behavior \& Organization 64 (1): 171-192.

Dillenberger, D. (2010). "Preferences for one-shot resolution of uncertainty and Allais-type behavior." Econometrica 78 (6): 1973-2004. 
Earnhart, D., \& Friesen, L. (2013). "Can punishment generate specific deterrence without updating? Analysis of a stated choice scenario." Environmental and Resource Economics 56 (3), 379-397.

Enachescu, J., Olsen, J., Kogler, C., Zeelenberg, M., Breugelmans, S. M., \& Kirchler, E. (2019). "The role of emotions in tax compliance behavior: A mixed-methods approach." Journal of Economic Psychology, 74: 102194.

Erard, B. (1992). "The influence of tax audits on reporting behavior", in J. Slemrod, ed., Why People Pay Taxes: Tax Compliance and Enforcement. Ann Arbor, MI: The University of Michigan Press, 95-114.

Erard, B., \& Feinstein, J. S. (1994). "Honesty and evasion in the tax compliance game." The RAND Journal of Economics 25 (1): 1-19.

Feinstein, J. S. (1991). "An econometric analysis of income tax evasion and its detection." The RAND Journal of Economics 22 (1): 14-35.

Fischbacher, U. (2007). "z-Tree: Zurich toolbox for ready-made economic experiments." Experimental Economics 10 (2): 171-178.

Frey, B. (1997). Not Just For the Money - An Economic Theory of Personal Motivation. Cheltenham, UK: Edward Elgar Publishing Limited.

Gemmell, N., \& Ratto, M. (2012). "Behavioral tesponses to taxpayer audits: Evidence from random taxpayer inquiries." National Tax Journal 65 (1): 33-58.

Greiner, B. (2015). "Subject pool recruitment procedures: Organizing experiments with orsee." Journal of the Economic Science Association 1 (1): 114-125.

Guala F., \& Mittone, L. (2005), "Experiments in economics: External validity and the robustness of phenomena." Journal of Economic Methodology 12: 495-515.

Hashimzade, N., Myles, G. D., \& Tran-Nam, B. (2013). "Applications of behavioural economics to tax evasion." Journal of Economic Surveys 27 (5): 941-977.

Harrison, G. W., Martinez-Correa, J., \& Swarthout, J. T. (2015). "Reduction of compound lotteries with objective probabilities: Theory and evidence." Journal of Economic Behavior and Organization 119: 32-55.

Haselhuhn, M. P., Pope, D. G., Schweitzer, M. E., \& Fishman, P. (2012). “The impact of personal experience on behavior: Evidence from video-rental fines." Management Science 58 (1), 52-61. 
Hu, F., \& Ben-Ner, L. (2020). "The effects of feedback on lying behavior: Experimental evidence." Journal of Economic Behavior and Organization 171: 24-34.

Internal Revenue Service (2019). Data Book, 2018, Publication 55B. Washington, D.C.: Internal Revenue Service.

Kahneman, D., \& Tversky, A. (1979). "Prospect theory: An analysis of decision under risk." Econometrica 47 (2): 263-292.

Kastlunger, B., Kirchler, E., Mittone, L., \& Pitters, J. (2009). "Sequences of audits, tax compliance, and taxpaying strategies." Journal of Economic Psychology 30 (3): 405-418.

Keen, M., \& Slemrod, J. (2017). "Optimal Tax Administration”. Journal of Public Economics 152: $133-142$.

Kirchler, E. (2007). The Economic Psychology of Tax Behavior. Cambridge, UK: Cambridge University Press.

Kirchler, E, Hoelzl, E., \& Wahl, I. (2008). "Enforced versus voluntary tax compliance: The 'slippery slope' framework." Journal of Economic Psychology 29 (2): 210-225.

Kleven, H. J., Knudsen, M. B., Kreiner, C. T., Pedersen, S., \& Saez, E. (2011). “Unwilling or unable to cheat? Evidence from a randomized tax audit experiment in Denmark." Econometrica 79 (3): 651-692.

Lederman, L. (2018), “Does enforcement reduce voluntary tax compliance?” Brigham Young University Law Review 3: 623-694.

Maciejovsky, B., Kirchler, E., \& Schwarzenberger, H. (2007). "Misperceptions of chance and loss repair: On the dynamics of tax compliance." Journal of Economic Psychology 28 (6): 678691.

Matsueda, R. L., Kreager, D. A., \& Huizinga, D. (2006). "Deterring delinquents: A rational choice model of theft and violence." American Sociological Review 71(1): 95-122.

McKee, M., Siladke, C. A., \& Vossler, C. A. (2018). "Behavioral dynamics of tax compliance when taxpayer assistance services are available." International Tax and Public Finance 25 (3): $722-756$.

Mendoza, J. P., Wielhouwer, J. L., \& Kirchler, E. (2017). "The backfiring effect of auditing on tax compliance." Journal of Economic Psychology 62: 284-294. 
Mittone, L. (2006). "Dynamic behaviour in tax evasion: An experimental approach." Journal of Socio-Economics 35 (5): 813-835.

Mittone, L., F. Panebianco, F., \& Santoro, A. (2017). "The bomb-crater effect of tax audits: Beyond the misperception of chance." Journal of Economic Psychology 61: 225-243.

Nagin, D. S. (2013a). "Deterrence in the twenty-first century." Crime and Justice 42 (1): 199-263.

Nagin, D. S. (2013b). "Deterrence: A review of the evidence by a criminologist for economists." Annual Review of Economics 5 (1): 83-105.

Nagin, D. S., Cullen, F. T., \& Jonson, C. L. (2009). "Imprisonment and reoffending." Crime and Justice 38 (1): 115-200.

Olsen, J., Kasper, M., Enachescu, J., Benk, S., Budak, T., \& Kirchler, E. (2018). Emotions and tax compliance among small business owners: An experimental survey. International Review of Law and Economics, 56: 42-52.

Polinsky, A. M., \& Shavell, S. (2000). "The economic theory of public enforcement of law." The Journal of Economic Literature 38 (1): 45-76.

Prokosheva, S. (2016). "Comparing decisions under compound risk and ambiguity: The importance of cognitive skills." Journal of Behavioral and Experimental Economics 64: 94-105.

Rablen, M. D. (2014). "Audit probability versus effectiveness: The Beckerian approach revisited." Journal of Public Economic Theory 16 (2): 322-342.

Scotchmer, S. and Slemrod, J., (1989), Randomness in tax enforcement, Journal of Public Economics 38 (1): 17-32.

Simonsohn, U., Karlsson, N., Loewenstein, G., \& Ariely, D. (2008). "The tree of experience in the forest of information: Overweighing experienced relative to observed information." Games and Economic Behavior 62 (1): 263-286.

Snow, A., \& Warren, R. S. (2007). “Audit uncertainty, Bayesian updating, and tax evasion." Public Finance Review 35 (5): 555-571.

Skinner, J., \& Slemrod, J. (1985). "An economic perspective on tax evasion." National Tax Journal 38 (3): 345-353.

Slemrod, J. (2019). “Tax compliance and enforcement.” The Journal of Economic Literature 57 (4): 904-954. 
Spicer, M. W., \& Hero, R. E. (1985). “Tax evasion and heuristics: A research note.” Journal of Public Economics 26 (2): 263-267.

Srinivasan, T. N. (1973). “Tax evasion: A model.” Journal of Public Economics 2 (4): 339-346.

Torgler, B. (2003) “Tax morale, rule-governed behaviour, and trust.” Constitutional Political Economy 14 (2): 119-140.

Tversky, A., \& Kahneman, D. (1973). “Availability: A heuristic for judging frequency and probability." Cognitive Psychology 5 (2): 207-232.

Yaniv, G. (1999) "Tax compliance and advance tax payments: A prospect theory analysis." National Tax Journal 53 (4): 753-764.

Yitzhaki, S. (1974). "A note on income tax evasion: A theoretical analysis.” Journal of Public Economics 3 (2): 201-202. 
$\underline{\text { Appendix A }}$

Experimental Task

Decision

- Your income is $2300 \mathrm{ECU}$

- The tax rate is $25 \%$

- The audit efficiency is $67 \%$

- The audit probability is $37 \%$ fine is $100 \%$ of the evaded amount that is detected

Please indicate how much income you declare by clicking on the bar below!

You can use a calculator to decide how much income you want to declare!

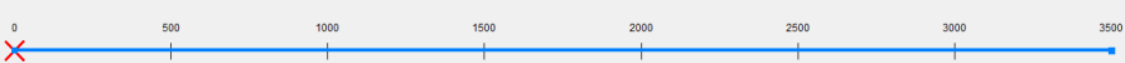

\begin{tabular}{|c|c|c|}
\hline $\begin{array}{l}\text { Audat } \\
\text { Auate endience }\end{array}$ & $\begin{array}{l}\text { No } \\
-\end{array}$ & $\begin{array}{l}\text { Yes } \\
67 \%\end{array}$ \\
\hline $\begin{array}{l}\text { Decalared income } \\
\text {-Taxes pasio }\end{array}$ & : & : \\
\hline $\begin{array}{l}=\text { Anter tax income } \\
\text {-Fine }\end{array}$ & 2300 & $\begin{array}{l}2300 \\
771\end{array}$ \\
\hline Income anter tares and fines & 2300 & 1530 \\
\hline
\end{tabular}

Declared income 0

Calculator $\times$

Declare income

Notes: Compliance choice for Task 23: "low audit effectiveness", "e first", $e=.67, p=.37$, detection risk =.24.

Feedback: Tax declaration is being audited

Feedback

Your tax declaration is being audited! 
Feedback: Audit result

Feedback

You did not declare 2300 ECU of your income.

The tax agency detected $67 \%$ of that amount!

Your income in this round is $1530 \mathrm{ECU}$. 


\section{$\underline{\text { Appendix B }}$}

Table B1: Effect of Experienced Fines on Post-audit Compliance

Dependent variable: Compliance rate

\begin{tabular}{|c|c|c|c|c|c|}
\hline & $\begin{array}{l}\text { One round } \\
\text { after audit }\end{array}$ & $\begin{array}{l}\text { Two rounds } \\
\text { after audit }\end{array}$ & $\begin{array}{c}\text { Three rounds } \\
\text { after audit }\end{array}$ & $\begin{array}{l}\text { Four rounds } \\
\text { after audit }\end{array}$ & $\begin{array}{l}\text { Five rounds } \\
\text { after audit }\end{array}$ \\
\hline Independent variable & (I) & (II) & (III) & (IV) & $(\mathrm{V})$ \\
\hline Intercept & $\begin{array}{c}0.3480^{* * *} \\
(0.0607)\end{array}$ & $\begin{array}{c}0.4219^{* * *} \\
(0.0557)\end{array}$ & $\begin{array}{c}0.3302^{* * *} \\
(0.0505)\end{array}$ & $\begin{array}{c}0.3059^{* * *} \\
(0.0477)\end{array}$ & $\begin{array}{c}0.2835^{* * *} \\
(0.0461)\end{array}$ \\
\hline Received income & $\begin{array}{c}0.0100^{* * *} \\
(0.0027)\end{array}$ & $\begin{array}{c}0.0190^{* * *} \\
(0.0028)\end{array}$ & $\begin{array}{c}0.0342^{* * *} \\
(0.0028)\end{array}$ & $\begin{array}{c}0.0416^{* * *} \\
(0.0027)\end{array}$ & $\begin{array}{c}0.0471^{* * *} \\
(0.0027)\end{array}$ \\
\hline Detection risk & $\begin{array}{c}0.0076^{* * *} \\
(0.0008)\end{array}$ & $\begin{array}{c}0.0068^{* * *} \\
(0.0008)\end{array}$ & $\begin{array}{c}0.0047^{* * *} \\
(0.0008)\end{array}$ & $\begin{array}{c}0.0043^{* * *} \\
(0.0008)\end{array}$ & $\begin{array}{c}0.0036^{* * *} \\
(0.0008)\end{array}$ \\
\hline Audit probability & $\begin{array}{l}-0.0010 \\
(0.0006)\end{array}$ & $\begin{array}{c}-0.0023^{* * *} \\
(0.0006)\end{array}$ & $\begin{array}{l}-0.0015^{*} \\
(0.0006)\end{array}$ & $\begin{array}{l}-0.0015^{*} \\
(0.0006)\end{array}$ & $\begin{array}{l}-0.0014^{*} \\
(0.0006)\end{array}$ \\
\hline Audit effectiveness & $\begin{array}{c}0.0015^{* * *} \\
(0.0004)\end{array}$ & $\begin{array}{c}0.0020^{* * *} \\
(0.0004)\end{array}$ & $\begin{array}{c}0.0035^{* * *} \\
(0.0004)\end{array}$ & $\begin{array}{c}0.0043^{* * *} \\
(0.0004)\end{array}$ & $\begin{array}{c}0.0047^{* * *} \\
(0.0004)\end{array}$ \\
\hline Audit probability first & $\begin{array}{l}-0.0028 \\
(0.0057)\end{array}$ & $\begin{array}{c}0.0034 \\
(0.0060)\end{array}$ & $\begin{array}{c}0.0011 \\
(0.0058)\end{array}$ & $\begin{array}{l}-0.0022 \\
(0.0057)\end{array}$ & $\begin{array}{c}0.0010 \\
(0.0056)\end{array}$ \\
\hline Round after audit & $\begin{array}{c}-0.1598^{* * *} \\
(0.0120)\end{array}$ & $\begin{array}{c}-0.1908^{* * *} \\
(0.0146)\end{array}$ & $\begin{array}{c}-0.2648^{* * *} \\
(0.0174)\end{array}$ & $\begin{array}{c}-0.2640^{* * *} \\
(0.0218)\end{array}$ & $\begin{array}{c}-0.1856^{* * *} \\
(0.0282)\end{array}$ \\
\hline Experienced fine & $\begin{array}{c}-0.2657^{* * *} \\
(0.0044)\end{array}$ & $\begin{array}{c}-0.3054^{* * *} \\
(0.0042)\end{array}$ & $\begin{array}{c}-0.3393^{* * *} \\
(0.0039)\end{array}$ & $\begin{array}{c}-0.3577^{* * *} \\
(0.0037)\end{array}$ & $\begin{array}{c}-0.3681^{* * *} \\
(0.0036)\end{array}$ \\
\hline $\begin{array}{l}\text { Round after audit } \mathrm{x} \\
\text { Experienced effectiveness }\end{array}$ & $\begin{array}{c}0.0023^{* * *} \\
(0.0002)\end{array}$ & $\begin{array}{l}0.0025^{* * *} \\
(0.0002)\end{array}$ & $\begin{array}{l}0.0038^{* * *} \\
(0.0003)\end{array}$ & $\begin{array}{l}0.0030^{* * *} \\
(0.0004)\end{array}$ & $\begin{array}{l}0.0022^{* * *} \\
(0.0005)\end{array}$ \\
\hline $\begin{array}{l}\text { Round after audit } \mathrm{x} \\
\text { Experienced fine }\end{array}$ & $\begin{array}{c}0.0056 \\
(0.0140)\end{array}$ & $\begin{array}{l}-0.0016 \\
(0.0171)\end{array}$ & $\begin{array}{l}-0.0535^{* *} \\
(0.0207)\end{array}$ & $\begin{array}{l}-0.0528^{*} \\
(0.0260)\end{array}$ & $\begin{array}{l}-0.0493 \\
(0.0336)\end{array}$ \\
\hline $\begin{array}{l}\text { Round after audit } \mathrm{x} \\
\text { Experienced effectiveness } \mathrm{x} \\
\text { Experienced fine }\end{array}$ & $\begin{array}{c}0.0019^{* * *} \\
(0.0002)\end{array}$ & $\begin{array}{l}0.0022^{* * *} \\
(0.0002)\end{array}$ & $\begin{array}{l}0.0027^{* * *} \\
(0.0003)\end{array}$ & $\begin{array}{l}0.0029^{* * *} \\
(0.0003)\end{array}$ & $\begin{array}{l}0.0028^{* * *} \\
(0.0004)\end{array}$ \\
\hline Demographic variables & included & included & included & included & included \\
\hline Observations & 8147 & 6244 & 5255 & 4723 & 4443 \\
\hline $\mathrm{N}$ & 333 & 333 & 333 & 333 & 333 \\
\hline $\mathrm{R}^{2}$ & 0.671 & 0.710 & 0.778 & 0.816 & 0.835 \\
\hline
\end{tabular}

Notes: * **, and *** indicate significance at the 10\%, 5\%, and 1\% level. Robust standard errors (in parentheses) are clustered at the individual level. Continuous predictors are scaled. 
Figure B1: Effect of Effective and Ineffective Audits Conditional on Experienced Fine

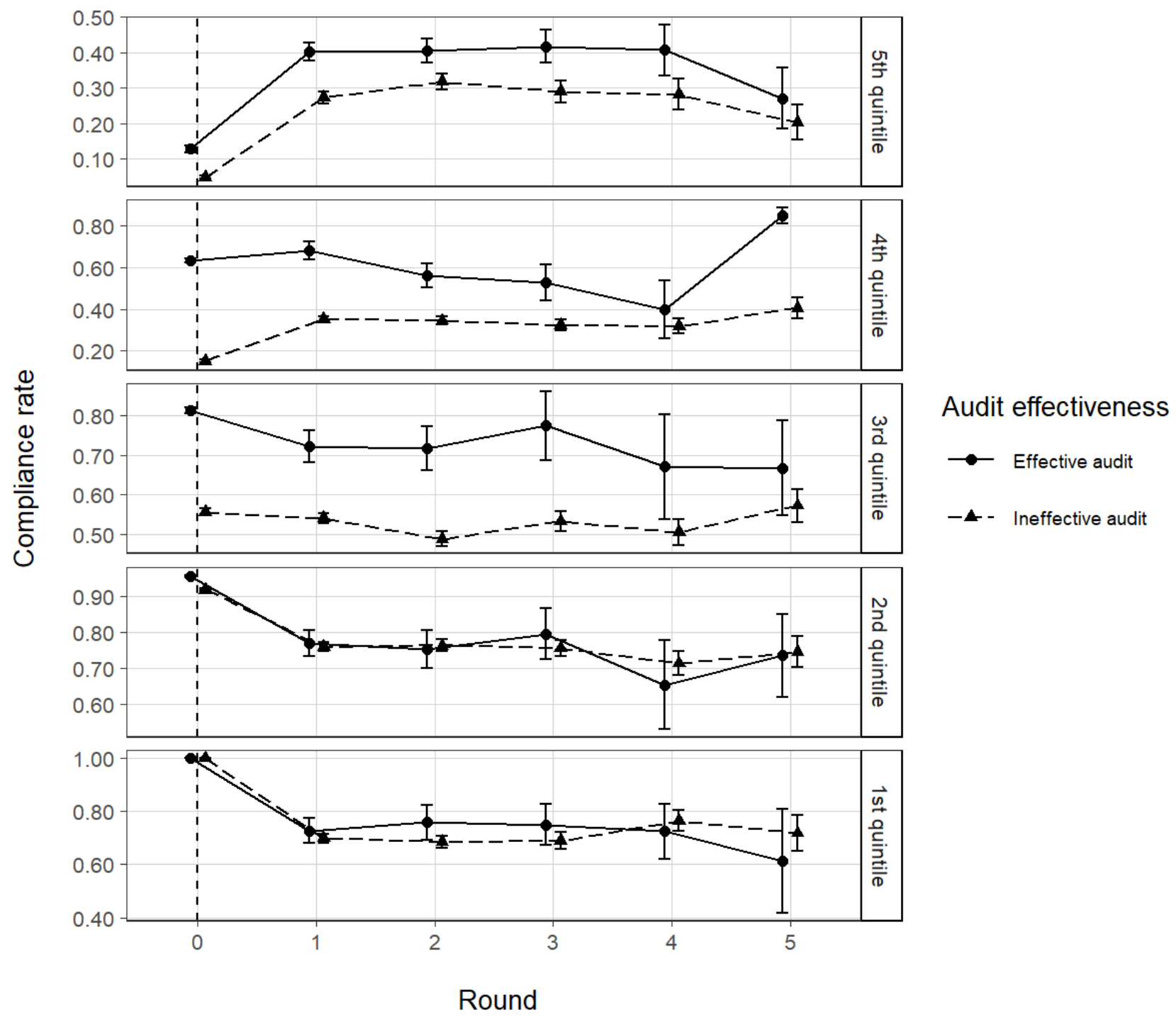

Notes: Taxpayers were audited after declaring their income in Round 0 (dashed vertical line) and not audited again through Round 5. Panel 1 ( $5^{\text {th }}$ quintile) comprises data from audited rounds that result in high fines (top 20 percent) as well as subsequent rounds. The mean Experienced fine is $338.30 \mathrm{ECU}(\mathrm{SD}=375.27)$. Effective audits detect all undeclared income. Ineffective audits detect between 30 percent and 70 percent of undeclared income. Error bars represent standard errors. 
Table B2: Effect of Audits One Round after the Audit (all Rounds)

\begin{tabular}{|c|c|c|c|c|c|c|}
\hline \multicolumn{7}{|l|}{ Dependent variable: Compliance rate } \\
\hline Independent variable & (VI) & (VII) & (VIII) & (IX) & $(\mathrm{X})$ & $(\mathrm{XI})$ \\
\hline Intercept & $\begin{array}{c}0.3018^{* * *} \\
(0.0414)\end{array}$ & $\begin{array}{l}0.3588^{* * *} \\
(0.0872)\end{array}$ & $\begin{array}{c}0.4455^{* * *} \\
(0.0345)\end{array}$ & $\begin{array}{c}0.4499^{* * *} \\
(0.0628)\end{array}$ & $\begin{array}{c}0.2414^{* * *} \\
(0.0380)\end{array}$ & $\begin{array}{c}0.2800^{* * *} \\
(0.0736)\end{array}$ \\
\hline Received income & $\begin{array}{c}-0.0180^{* * *} \\
(0.0030)\end{array}$ & $\begin{array}{c}-0.0181^{* * *} \\
(0.0030)\end{array}$ & $\begin{array}{c}-0.01633^{* * *} \\
(0.0027)\end{array}$ & $\begin{array}{c}-0.0164^{* * *} \\
(0.0027)\end{array}$ & $\begin{array}{c}-0.0135^{* * *} \\
(0.0029)\end{array}$ & $\begin{array}{c}-0.0136^{* * *} \\
(0.0029)\end{array}$ \\
\hline Detection risk & $\begin{array}{c}0.0089^{* * *} \\
(0.0009)\end{array}$ & $\begin{array}{c}0.0089^{* * *} \\
(0.0009)\end{array}$ & $\begin{array}{c}0.0055^{* * *} \\
(0.0008)\end{array}$ & $\begin{array}{c}0.0056^{* * *} \\
(0.0008)\end{array}$ & $\begin{array}{c}0.0081^{* * *} \\
(0.0008)\end{array}$ & $\begin{array}{c}0.0081^{* * *} \\
(0.0008)\end{array}$ \\
\hline Audit probability & $\begin{array}{l}-0.0001 \\
(0.0006)\end{array}$ & $\begin{array}{l}-0.0001 \\
(0.0006)\end{array}$ & $\begin{array}{l}0.0013^{* *} \\
(0.0005)\end{array}$ & $\begin{array}{l}0.0013^{* *} \\
(0.0005)\end{array}$ & $\begin{array}{l}-0.0006 \\
(0.0006)\end{array}$ & $\begin{array}{l}-0.0006 \\
(0.0006)\end{array}$ \\
\hline Audit effectiveness & $\begin{array}{c}0.0000 \\
(0.0004)\end{array}$ & $\begin{array}{c}0.0000 \\
(0.0004)\end{array}$ & $\begin{array}{c}0.0006 \\
(0.0004)\end{array}$ & $\begin{array}{c}0.0006 \\
(0.0004)\end{array}$ & $\begin{array}{l}-0.0002 \\
(0.0004)\end{array}$ & $\begin{array}{l}-0.0002 \\
(0.0004)\end{array}$ \\
\hline Audit probability first & $\begin{array}{c}0.0028 \\
(0.0063)\end{array}$ & $\begin{array}{c}0.0029 \\
(0.0063)\end{array}$ & $\begin{array}{l}-0.0009 \\
(0.0056)\end{array}$ & $\begin{array}{l}-0.0008 \\
(0.0056)\end{array}$ & $\begin{array}{c}0.0046 \\
(0.0060)\end{array}$ & $\begin{array}{c}0.0046 \\
(0.0060)\end{array}$ \\
\hline Audit last round & $\begin{array}{c}-0.0260^{* *} \\
(0.0132)\end{array}$ & $\begin{array}{l}-0.0259^{*} \\
(0.0132)\end{array}$ & $\begin{array}{c}-0.0689^{* * *} \\
(0.0123)\end{array}$ & $\begin{array}{c}-0.0695^{* * *} \\
(0.0123)\end{array}$ & $\begin{array}{c}0.04422^{* * *} \\
(0.0131)\end{array}$ & $\begin{array}{c}0.0444^{* * *} \\
(0.0131)\end{array}$ \\
\hline $\begin{array}{l}\text { Audit last round x Experienced } \\
\text { effectiveness }\end{array}$ & $\begin{array}{c}0.0006^{* * *} \\
(0.0002)\end{array}$ & $\begin{array}{c}0.0006^{* * *} \\
(0.0002)\end{array}$ & $\begin{array}{c}0.0001 \\
(0.0002)\end{array}$ & $\begin{array}{c}0.0001 \\
(0.0002)\end{array}$ & $\begin{array}{c}0.0006^{* * *} \\
(0.0002)\end{array}$ & $\begin{array}{c}0.0006^{* * *} \\
(0.0002)\end{array}$ \\
\hline Dishonest & & & $\begin{array}{c}-0.5473^{* * *} \\
(0.0097)\end{array}$ & $\begin{array}{c}-0.5436^{* * *} \\
(0.0097)\end{array}$ & & \\
\hline Audit last round $\mathrm{x}$ Noncompliant & & & $\begin{array}{c}0.2644^{* * *} \\
(0.0124)\end{array}$ & $\begin{array}{c}0.2647^{* * *} \\
(0.0124)\end{array}$ & & \\
\hline Honest & & & & & $\begin{array}{c}0.4678^{* * *} \\
(0.0103)\end{array}$ & $\begin{array}{c}0.4658^{* * *} \\
(0.0103)\end{array}$ \\
\hline Audit last round $\mathrm{x}$ Compliant & & & & & $\begin{array}{c}-0.3047^{* * *} \\
(0.0131)\end{array}$ & $\begin{array}{c}-0.3046^{* * *} \\
(0.0131)\end{array}$ \\
\hline Demographic variables & & included & & included & & included \\
\hline Observations & 9324 & 9324 & 9324 & 9324 & 9324 & 9324 \\
\hline $\mathrm{N}$ & 333 & 333 & 333 & 333 & 333 & 333 \\
\hline $\mathrm{R}^{2}$ & 0.612 & 0.581 & 0.603 & 0.617 & 0.592 & 0.595 \\
\hline
\end{tabular}

Notes: $*{ }^{* *}$, and $* * *$ indicate significance at the $10 \%, 5 \%$, and $1 \%$ level. Robust standard errors (in parentheses) are clustered at the individual level. Continuous predictors are scaled. 
Table B3: Effect of First Audits on Dishonest and Honest Taxpayers (all Rounds)

Dependent variable: Compliance rate

\begin{tabular}{|c|c|c|c|c|}
\hline Independent variable & (XII) & (XIII) & (XIV) & $(\mathrm{XV})$ \\
\hline Intercept & $\begin{array}{c}0.4402^{* * *} \\
(0.1002)\end{array}$ & $\begin{array}{c}0.4169^{* * *} \\
(0.1306)\end{array}$ & $\begin{array}{c}0.3087^{* * *} \\
(0.1009)\end{array}$ & $\begin{array}{c}0.2892^{* *} \\
(0.1350)\end{array}$ \\
\hline Received income & $\begin{array}{l}-0.0047 \\
(0.0080)\end{array}$ & $\begin{array}{l}-0.0041 \\
(0.0080)\end{array}$ & $\begin{array}{l}-0.0044 \\
(0.0080)\end{array}$ & $\begin{array}{l}-0.0037 \\
(0.0081)\end{array}$ \\
\hline Detection risk & $\begin{array}{c}0.0116^{* * *} \\
(0.0023)\end{array}$ & $\begin{array}{c}0.0119^{* * *} \\
(0.0024)\end{array}$ & $\begin{array}{c}0.0114^{* * *} \\
(0.0024)\end{array}$ & $\begin{array}{c}0.0118^{* * *} \\
(0.0024)\end{array}$ \\
\hline Audit probability & $\begin{array}{l}-0.0015 \\
(0.0017)\end{array}$ & $\begin{array}{l}-0.0017 \\
(0.0017)\end{array}$ & $\begin{array}{l}-0.0015 \\
(0.0017)\end{array}$ & $\begin{array}{l}-0.0017 \\
(0.0017)\end{array}$ \\
\hline Audit effectiveness & $\begin{array}{l}-0.0006 \\
(0.0011)\end{array}$ & $\begin{array}{l}-0.0008 \\
(0.0011)\end{array}$ & $\begin{array}{l}-0.0006 \\
(0.0011)\end{array}$ & $\begin{array}{l}-0.0007 \\
(0.0011)\end{array}$ \\
\hline Audit probability first & $\begin{array}{c}0.0034 \\
(0.0170)\end{array}$ & $\begin{array}{c}0.0042 \\
(0.0171)\end{array}$ & $\begin{array}{c}0.0093 \\
(0.0171)\end{array}$ & $\begin{array}{c}0.0079 \\
(0.0171)\end{array}$ \\
\hline Audit last round & $\begin{array}{l}-0.0055 \\
(0.0170)\end{array}$ & $\begin{array}{l}-0.0069 \\
(0.0171)\end{array}$ & $\begin{array}{c}0.0181 \\
(0.0173)\end{array}$ & $\begin{array}{c}0.0178 \\
(0.0174)\end{array}$ \\
\hline Dishonest & $\begin{array}{c}-0.6138^{* * *} \\
(0.0605)\end{array}$ & $\begin{array}{c}-0.5347^{* * *} \\
(0.0601)\end{array}$ & & \\
\hline Audit last round $\mathrm{x}$ Dishonest & $\begin{array}{c}0.1540^{* * *} \\
(0.0529)\end{array}$ & & & \\
\hline Honest & & & $\begin{array}{c}0.4600^{* * *} \\
(0.0584)\end{array}$ & $\begin{array}{c}0.3749^{* * *} \\
(0.0602)\end{array}$ \\
\hline Audit last round $\mathrm{x}$ Honest & & & $\begin{array}{l}-0.0801 \\
(0.0488)\end{array}$ & $\begin{array}{l}-0.0779 \\
(0.0492)\end{array}$ \\
\hline Demographic variables & & included & & included \\
\hline Observations & 1181 & 1181 & 1181 & 1181 \\
\hline $\mathrm{N}$ & 333 & 333 & 333 & 333 \\
\hline $\mathrm{R}^{2}$ & 0.676 & 0.669 & 0.689 & 0.684 \\
\hline
\end{tabular}

Notes: $* * *$, and $* * *$ indicate significance at the $10 \%, 5 \%$, and $1 \%$ level. Robust standard errors (in parentheses) are clustered at the individual level. Continuous predictors are scaled. 
Table B4: Effect of Audits on Evaded Income One Round after the Audit

\begin{tabular}{|c|c|c|c|c|c|}
\hline \multicolumn{6}{|l|}{ Dependent variable: Evaded Income } \\
\hline \multirow[b]{2}{*}{ Independent variable } & \multicolumn{3}{|c|}{ Aggregate effect } & \multicolumn{2}{|c|}{ Effect of first audit } \\
\hline & $(\mathrm{XVI})$ & (XVII) & $\mathrm{X}(\mathrm{VIII})$ & (XIX) & $(\mathrm{XX})$ \\
\hline Intercept & $\begin{array}{c}1751.0874^{* * *} \\
(254.4807)\end{array}$ & $\begin{array}{c}1976.6103^{* * *} \\
(218.2346)\end{array}$ & $\begin{array}{c}1413.2132^{* * *} \\
(184.9973)\end{array}$ & $\begin{array}{c}1621.9170^{* * *} \\
(529.0160)\end{array}$ & $\begin{array}{c}1930.4631^{* * *} \\
(553.5839)\end{array}$ \\
\hline Received income & $\begin{array}{l}233.8380^{* * *} \\
(8.5125)\end{array}$ & $\begin{array}{l}223.9386^{* * *} \\
(8.3077)\end{array}$ & $\begin{array}{l}225.1960^{* * *} \\
(7.8109)\end{array}$ & $\begin{array}{c}154.4487^{* * *} \\
(35.2222)\end{array}$ & $\begin{array}{l}159.2713^{* * *} \\
(36.3148)\end{array}$ \\
\hline Detection risk & $\begin{array}{l}-21.7878^{* * *} \\
(2.4644)\end{array}$ & $\begin{array}{l}-18.2884^{* * *} \\
(2.4053)\end{array}$ & $\begin{array}{l}-14.3268^{* * *} \\
(2.2668)\end{array}$ & $\begin{array}{l}-29.6249^{* * *} \\
(10.6482)\end{array}$ & $\begin{array}{l}-32.5972^{* * *} \\
(11.0103)\end{array}$ \\
\hline Audit probability & $\begin{array}{l}-1.6236 \\
(1.8072)\end{array}$ & $\begin{array}{l}-1.0998 \\
(1.7628)\end{array}$ & $\begin{array}{c}-3.9564^{* *} \\
(1.6595)\end{array}$ & $\begin{array}{c}2.8631 \\
(7.8824)\end{array}$ & $\begin{array}{c}4.4694 \\
(8.1252)\end{array}$ \\
\hline Audit effectiveness & $\begin{array}{l}-0.9267 \\
(1.2483)\end{array}$ & $\begin{array}{l}-0.8464 \\
(1.2176)\end{array}$ & $\begin{array}{l}-1.4162 \\
(1.1462)\end{array}$ & $\begin{array}{c}0.9793 \\
(5.4049)\end{array}$ & $\begin{array}{c}2.2718 \\
(5.5881)\end{array}$ \\
\hline Audit probability first & $\begin{array}{c}9.6645 \\
(18.1273)\end{array}$ & $\begin{array}{c}10.7328 \\
(17.6788)\end{array}$ & $\begin{array}{c}11.6946 \\
(16.6409)\end{array}$ & $\begin{array}{c}19.5717 \\
(76.8972)\end{array}$ & $\begin{array}{l}-16.4343 \\
(79.5490)\end{array}$ \\
\hline Round after audit & $\begin{array}{l}85.0889^{* *} \\
(35.0975)\end{array}$ & $\begin{array}{c}-117.2726^{* * *} \\
(35.6436)\end{array}$ & $\begin{array}{c}237.1545^{* * *} \\
(34.0904)\end{array}$ & $\begin{array}{c}33.7191 \\
(63.1871)\end{array}$ & $\begin{array}{l}-80.7758 \\
(63.9287)\end{array}$ \\
\hline $\begin{array}{l}\text { Round after audit x Experienced } \\
\text { effectiveness }\end{array}$ & $\begin{array}{c}-1.7158^{* * *} \\
(0.5348)\end{array}$ & $\begin{array}{c}-1.7950^{* * *} \\
(0.5216)\end{array}$ & $\begin{array}{l}-0.6975 \\
(0.4941)\end{array}$ & & \\
\hline Noncompliant & & & $\begin{array}{c}1433.7787^{* * *} \\
(29.8289)\end{array}$ & & \\
\hline Round after audit $\mathrm{x}$ Noncompliant & & & $\begin{array}{l}-777.1469^{* * *} \\
(35.1549)\end{array}$ & & \\
\hline Compliant & & $\begin{array}{c}-1135.5209^{* * *} \\
(30.3969)\end{array}$ & & & \\
\hline Round after audit $\mathrm{x}$ Compliant & & $\begin{array}{l}780.0467^{* * *} \\
(36.0062)\end{array}$ & & & \\
\hline Dishonest & & & & $\begin{array}{c}1545.7704^{* * *} \\
(176.1982)\end{array}$ & \\
\hline Round after audit $\mathrm{x}$ Dishonest & & & & $\begin{array}{c}-514.9945^{* * *} \\
(186.8062)\end{array}$ & \\
\hline Honest & & & & & $\begin{array}{c}-1061.5841^{* * *} \\
(177.3145)\end{array}$ \\
\hline Round after audit $\mathrm{x}$ Honest & & & & & $\begin{array}{l}297.3044^{*} \\
(172.8129)\end{array}$ \\
\hline Demographic variables & included & included & included & Included & included \\
\hline Observations & 8147 & 8147 & 8147 & 666 & 666 \\
\hline $\mathrm{N}$ & 333 & 333 & 333 & 333 & 333 \\
\hline $\mathrm{R}^{2}$ & 0.638 & 0.629 & 0.635 & 0.575 & 0.595 \\
\hline
\end{tabular}

Notes: $* * *$, and $* * *$ indicate significance at the $10 \%, 5 \%$, and $1 \%$ level. Robust standard errors (in parentheses) are clustered at the individual level. Continuous predictors are scaled. 